\title{
Non-Forest Woody Vegetation (Scattered Greenery) Case Study of the Samopše Settlement, Czech Republic
}

\author{
Zuzana Vondra Krupková ${ }^{1}$ \\ ${ }^{1}$ Department of Landscape Architecture; Faculty of Agrobiology, Food and Nature Resources, Czech University \\ of Life Sciences; Prague; Czech Republic \\ Correspondence: Zuzana Vondra Krupková, Department of Landscape Architecture, Faculty of Agrobiology, \\ Food and Nature Resources, Czech University of Life Sciences Prague, Kamýcká 129, 16500 Prague 6-Suchdol, \\ Czech Republic. Tel: 420-774-315-361, 354-864-3249. E-mail: vojvondra@gmail.com
}

Received: September 10, 2018

Accepted: September 20, 2018

Online Published: September 30, 2018

doi:10.5539/enrr.v8n3p214

URL: https://doi.org/10.5539/enrr.v8n3p214

\begin{abstract}
The development and management of the Czech landscape has been influenced by several key factors in the past. One important factor is the development of society, particularly political changes and ecological development. Others include the level of knowledge and understanding of technologies, scientific knowledge and the non-productive importance of the landscape, as well as the attitude of society and individuals towards the landscape. In the past, non-forest woody vegetation was a standard part of the European agricultural landscape and formed its typical appearance. The onset of collective farming during the second half of the twentieth century resulted in transforming the landscape into open fields without permanent vegetation. The landscape became everyone's and no-one's and was subject to orders, tasks and plans. The key goal of this article is to evaluate non-forest woody vegetation from a landscape-ecological aspect and compare the occurrence of non-forest woody vegetation in four landscape types. The submitted study presents various types of non-forest woody vegetation, the species present in elements of scattered greenery and the spatial arrangement depending on the method of management and use of the territory.
\end{abstract}

Keywords: non-forest woody vegetation, landscape vegetation, landscape greenery, scattered greenery, landscape sustainability, landscape structure, landscape character. landscape sustainability

\section{Introduction}

Vegetation fulfils a specific and irreplaceable function in the landscape in relation to the cycle of matter and energy flow. Production of biomass provides food for herbivores and is the main source of organic material in the soil. It accelerates the weathering of rocks and contributes towards the creation and development of soil and consolidation of the earth's surface, thereby preventing erosion. More extensive removal of vegetation from the landscape leads to unavoidable water and wind erosion, changes in the dissipation of the sun's energy and subsequent changes in air flow and rain distribution (Trnka, 2007). Scattered greenery refers to all vegetation and solitary specimens, including undergrowth, that is not forest, agricultural crops or a part of the system of vegetation in a town residential area or other development in the landscape (Trnka, 2007).

\subsection{Historical Development of the European Landscape and Landscape Vegetation}

A decisive period in the development of the natural characteristics of the current landscape was the Quaternary Period. The Quaternary gave today's topographical relief its basic form and provided the onset of current plant and animal societies. Librová (1996) differentiates three phases of development in the period between the Neolithic and the present day from the aspect of human influence on the landscape: (a) Primary homeostasis typical for a period of minimal human influence in the natural landscape; (b) Secondary homeostasis - the cultivated landscape of previous centuries characterised by deforestation, cultivation and urbanisation; (c) Tertiary homeostasis - follows the period of industrial development and ecologically unsustainable use of nature and natural resources. Means a return to procedures in agriculture, forestry and water management that are close to nature, renewal of biodiversity and ecological balance. 


\subsection{The Initial Role of Humans in the Historical Context of the Development of the Landscape}

Humans were fully dependent on nature throughout the entire Palaeolithic (Early Stone Age) and Mesolithic (Middle Stone Age). It was only in the Neolithic (Later Stone Age) that the human impact on vegetation and forests increased as nomadic hunters gradually became herders and farmers and established relatively permanent settlements. The region of Central Europe was covered by mixed forests of oak, elm and lime trees to high altitudes, with spruce forests growing in the mountains and mountain pine growing even higher. During this time, Neolithic people began affecting the landscape by pasturing herds, farming soil and expanding agricultural areas and affecting the structure of the landscape. The Slavs appeared in Central Europe around the middle of the first millennium. The onset of the High Middle Ages meant fundamental and rapid changes in the landscapedeforestation and an overall change to the character of the landscape and the origins of an intensively used, park-type landscape with a dense mosaic of pastures and fields (Schama, 1995). The period of the first great colonisation was followed by the period of the Hussite wars, which destroyed the entire region. In the fifteenth century, sheep husbandry, pond management and spontaneous forestation flourished. Extraction of ore and its processing in particular (charcoal use in metallurgical processes) resulted in the devastation of forests. Wood was transported over waterways and resulted in the necessary regulation of watercourses (Schama, 1995). The Thirty Years' War devastated the land and decreased the population and settlements (Löw \& Míchal, 2003). Due to industrialisation, society began to create a cohesive and completely transformed space that displaced the natural landscape.

\subsection{The Landscape of the Czech Republic in the Twentieth Century}

The twentieth century was a period of fundamental change and dramatic reversals (Sklenička, 2003) in the development of the landscape in what is the Czech Republic today. After the Second World War, the German population was displaced from the border zone, which was subsequently colonised by Czech nationals (approx. 1.7 million ha) by decree of President E. Beneš - No. 12/1945 on the settlement of agricultural land confiscated in this manner (Petráň, 1985). The initial intervention into the agricultural landscape occurred during the first years of existence of the JZD (Agricultural Cooperative Units), when the first field borders and secondary field tracks were eliminated and the proportion of chemical protection of plants was increased. In subsequent decades, other stabilising landscape elements also disappeared - meadows near springs and water meadows near streams, field borders, a number of field tracks, solitary and line vegetation, groves, sunken lanes and areas of fallow land which were cultivated (Lokoč \& Lokočová, 2010). Collectivisation led to the destruction of personal property and became famous for ploughing field borders during the 1950s, initiated intensive erosion processes, caused water management conditions to worsen and broke people's emotional connections to the rural landscape. The landscape became an area for mass production (Lokoč \& Lokočová, 2010). The merging of enterprises into large units covering multiple cadastres and the use of chemicals in plant production was also a negative aspect. The ability to effectively eliminate weeds using chemicals and fertilise arbitrarily led to the neglect of sowing procedures (Löw \& Míchal, 2003). Opposition to private ownership of land eliminated personal responsibility for its condition and appearance. Reduction of grassland areas and their transformation into ploughed land (on average $75 \%$ of agricultural land was ploughed, in some cases up to $100 \%$ ) increased wind and water erosion by up to ten times. Erosion was also caused by growing wide row crops (sweet corn, potatoes and beet) on sloping land (hilly areas and highlands). Unfortunately, this situation persists in a number of areas in our landscape today - over half of ploughed land is at risk (Lipský, 2000). The aesthetic value of the agricultural landscape was noticeably reduced and particularly indicates the loss of variety of stimuli in a rugged and varied cultivated landscape and its transformation into a repetitious and monotonous production area (Doucha, 2001). Agriculture was subject to the pressure of increasing production, which corresponded to an intolerable degree of intensification (Cílek, 2011). Immediately after 1989, agricultural activities which had led to the predominance of agricultural land in the landscape were supressed. A period of restoration of the non-productive functions of the landscape began (Lokoč \& Lokočová, 2010).

\subsection{Non-Forest Woody Vegetation}

Non-forest woody vegetation includes trees and bushes, groups or lines, spot or blanket elements (Table 1), that grow on non-forest land (Bulír \& Škorpík, 1988). Scattered greenery "distinguishes all growth and solitary specimens of woody plants, including undergrowth, that are not part of a forest, agricultural cultivation or system of vegetation in a town residential area or other development in the landscape" (Bulír \& Škorpík, 1988). 
Table 1. Categories of landscape vegetation (non-forest woody vegetation) in the Czech Republic. (Source: Prudký, (2001); Sklenička, (2003); Sláviková,( 1984); Trnka, (2001); Supuka, Schlampová \& Jančura, (1999)).

\begin{tabular}{lll}
\hline $\begin{array}{c}\text { Non-forest woody vegetation } \\
\text { elements }\end{array}$ & Defined features and spatial parameters & Examples of non-forest woody vegetation elements \\
\hline Blanket & min. area $50 \mathrm{~m}^{2}$, max. area $0.3 \mathrm{ha}$ & groves, copses, bush growth \\
& min. length $30 \mathrm{~m}$, max. width $30 \mathrm{~m}$, & $\begin{array}{l}\text { growth on banks, tree avenues along roads, field } \\
\text { borders, windbreaks, hedgerows } \\
\text { Line }\end{array}$ \\
& width max. $30 \%$ of the length & $\begin{array}{l}\text { solitary tree/bush or clusters of trees/bushes, } \\
\text { frequently surrounding minor artefacts in the } \\
\text { landscape, such as crosses, chapels, memorials }\end{array}$ \\
\hline
\end{tabular}

\section{Material and Methods}

A detailed field survey was performed in the model research area to acquire the necessary information about the area, condition and type of scattered greenery elements. The comprehensive research methodology includes a dendrological survey of the current condition of non-forest woody structure growth according to typology (Bulír \& Škorpík, 1988) and the vitality of scattered greenery structures according to methodology (Mareček, 1986). The vitality of vegetation elements was determined according to physiological age, physiological condition (vitality), mechanical condition (state of health, operating safety) and supplementary values (aesthetic, ecological importance of trees, location within a composition, etc.). The vitality of vegetation elements was evaluated using a four-point scale: A - woody plants that were vital, with a high plantation value and long-term existence; $\mathbf{B}-$ damaged and older woody plants; $\mathbf{C}$ - old or damaged woody plants, practically characteristic for the specific area of interest; D - damaged woody plants, low plantation value, removal necessary. Evaluation of the suitability of species according to the Map of Potentially Natural Vegetation in the Czech Republic (Neuhäuslová et al., 1998) comprises: Aa - a vegetation element typical of the landscape character of the area surveyed according to the MPNV; Bb - an element corresponding to the landscape character with small exceptions; Cc - over $40 \%$ of the vegetation element does not correspond to the landscape character; Dd - the vegetation element and species compositions do not correspond to the landscape character of the area of interest (Koblížek, 2000; Vondra Krupková, 2018). Particular attention is given to the dendrological survey and areas of individual existing elements of non-forest woody vegetation (land survey 2016-2017). The field survey was based on a landscape assessment of scattered greenery in the open landscape. The survey took place according to previously executed assessments. The purpose of creating an inventory was to acquire information about the composition of growth and its vitality and suitability, which could then be used to devise a management strategy for scattered greenery in the areas examined. From a forestry and dendrological point of view and in combination with the typology of vegetation, materials were then created for general rules that could establish, design, assess and maintain the functionality of non-forest woody vegetation elements, as well as preserve or expand the biodiversity of individual locations in compliance with individual vegetation types.

\section{Results}

\subsection{Model Area}

Samopše is located in the district of Kutná Hora (Fig. 1) at the south-eastern edge of the Central Bohemian Region, which is part of the Bohemian Massif and one of the oldest parts of the European continent. It spreads across the northern edge of the Bohemian-Moravian Highlands between the central watercourses of the Sázava and Labe rivers. The area of this district does not have a unified natural character. Many various geological influences have affected its appearance. It is one of three orographic units the Bohemian-Moravian Highlands, the Č́slava Basin and the Labe Lowlands. The selected area is interesting from its natural and cultural-historical aspects. A typical feature of the village of Samopše (Fig. 1) is the presence of several landscape types (Table 2), including the deeply cut valley of the Sázava River and the related importance of the area in terms of extra-regional and regional territorial ecological stability systems. The farming methods used by local residents were dependent on the natural conditions predetermined by the shape of the landscape in which they lived. The result of their long-term activities is a different landscape structure in individual settlements, which gives this area a specific and typical landscape character. 


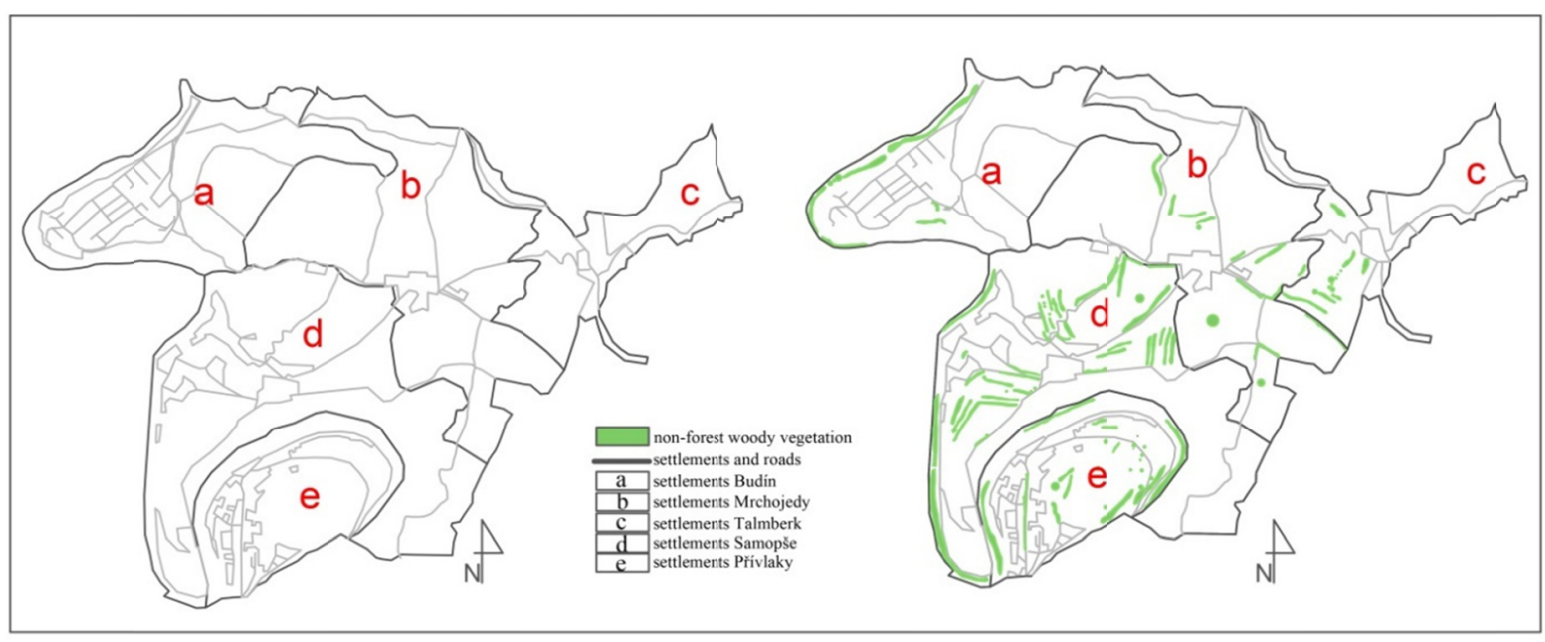

Figure 1. Map of the cadastral area of the village of Samopše, case study of the system of non-forest woody vegetation and division of the area into individual settlements. (Source: author's elaboration)

The village of Samopše spreads along the right bank of the Sázava River at an altitude of 345 metres above sea level. The municipality includes five settlements: Př́ívlaky, Talmberk, Budín, Mrchojedy and Samopše (Table 2). The total cadastral area of the municipality is $7,302,435 \mathrm{~m}^{2}$, ploughed land comprising $\left(1,173 \mathrm{~km}^{2}\right) 14 \%$ of this area. About one third $\left(2.88 \mathrm{~km}^{2}\right)$ of the cadastre of the village is forest growth, another part of the cadastral area is permanent grassland $\left(1.85 \mathrm{~km}^{2}\right)$ and the cadastre of the village also includes fruit orchards. From the aspect of various landscape types, individual settlements divide the area into 5 sections (Table 2).

Table 2. Division of the area examined into five separate settlements: Budín, Př́vlaky, Talmberk, Mrchojedy, Samopše and their landscape character. (Source: author's elaboration based on Vondra Krupková, 2018; Löw \& Novák, 2003)

\begin{tabular}{|c|c|c|c|c|c|}
\hline Name of settlement & Budín & Přívlaky & Talmberk & Mrchojedy & Samopše \\
\hline Total area of the cadastre territory $\left(\mathrm{m}^{2}\right)$ & $1,400,000$ & 900,000 & 680,000 & $1,798,435$ & $2,524,000$ \\
\hline Total area of forest $\left(\mathrm{km}^{2}\right)$ & $0.79 \mathrm{~km}^{2}$ & $0.05 \mathrm{~km}^{2}$ & $0.33 \mathrm{~km}^{2}$ & $0.72 \mathrm{~km}^{2}$ & $0.99 \mathrm{~km}^{2}$ \\
\hline Total area of fields $\left(\mathrm{km}^{2}\right)$ & $0.003 \mathrm{~km}^{2}$ & $0.04 \mathrm{~km}^{2}$ & $0.06 \mathrm{~km}^{2}$ & $0.9 \mathrm{~km}^{2}$ & $0.17 \mathrm{~km}^{2}$ \\
\hline Total area of meadows $\left(\mathrm{km}^{2}\right)$ & $0.12 \mathrm{~km}^{2}$ & $0.63 \mathrm{~km}^{2}$ & $0.24 \mathrm{~km}^{2}$ & $0.11 \mathrm{~km}^{2}$ & $0.75 \mathrm{~km}^{2}$ \\
\hline Total area of settlement $\left(\mathrm{km}^{2}\right)$ & $0.27 \mathrm{~km}^{2}$ & $0.15 \mathrm{~km}^{2}$ & $0.11 \mathrm{~km}^{2}$ & $0.054 \mathrm{~km}^{2}$ & $0.23 \mathrm{~km}^{2}$ \\
\hline Total area of bodies of water $\left(\mathrm{km}^{2}\right)$ & $0.14 \mathrm{~km}^{2}$ & $0.12 \mathrm{~km}^{2}$ & $0.0028 \mathrm{~km}^{2}$ & $0.00044 \mathrm{~km}^{2}$ & $0.45 \mathrm{~km}^{2}$ \\
\hline $\begin{array}{l}\text { Types of landscape according to Löw \& Novák } \\
\text { (2006) }\end{array}$ & $\begin{array}{c}\text { Forest } \\
\text { landscape }\end{array}$ & $\begin{array}{l}\text { Deep valley } \\
\text { landscape }\end{array}$ & $\begin{array}{l}\text { Forest-agricultural } \\
\text { landscape }\end{array}$ & $\begin{array}{l}\text { Agricultural } \\
\text { landscape }\end{array}$ & $\begin{array}{l}\text { Forest-agricultural } \\
\text { landscape }\end{array}$ \\
\hline
\end{tabular}

According to the Map of Potentially Natural Vegetation (MPNV), the area of interest falls within a region of oak and/or fir woodland (Luzulo albidae-Quercetum petraeae, Abieti-Quercetum) and lime-beech woodland with small-leaved lime (Tilio-cordatae Fagetum). We will establish whether the non-forest woody vegetation in the area of interest falls within the range of natural ecosystems for this area by performing a detailed inventory.

\subsection{BudÍN Settlement}

The Budín settlement (Fig. 2) spreads across the north-western section of the area examined. The total area of the settlement is $1,400,000 \mathrm{~m}^{2}$. The boundaries defining the area for the gathered inventory and research is determined by the deeply-cut bed of the Sázava River in the southern and north-western part of the area and the boundary of the settlement to the northeast and southeast comprising mixed forest. From the north, the boundary of the settlement is determined by the cadastral border which follows the existing road. The character of the landscape is woodland, which Löw \& Novák (2006) define as "less transformed by human intervention and a 
rare to natural type of landscape. This type of landscape is distinguished by forest growth (at last $70 \%$ of the area). Apart from some exceptions, these are the basic type of matrices of potential vegetation in the Czech Republic. They are of a visually enclosed character" (Vondra Krupková, 2018).

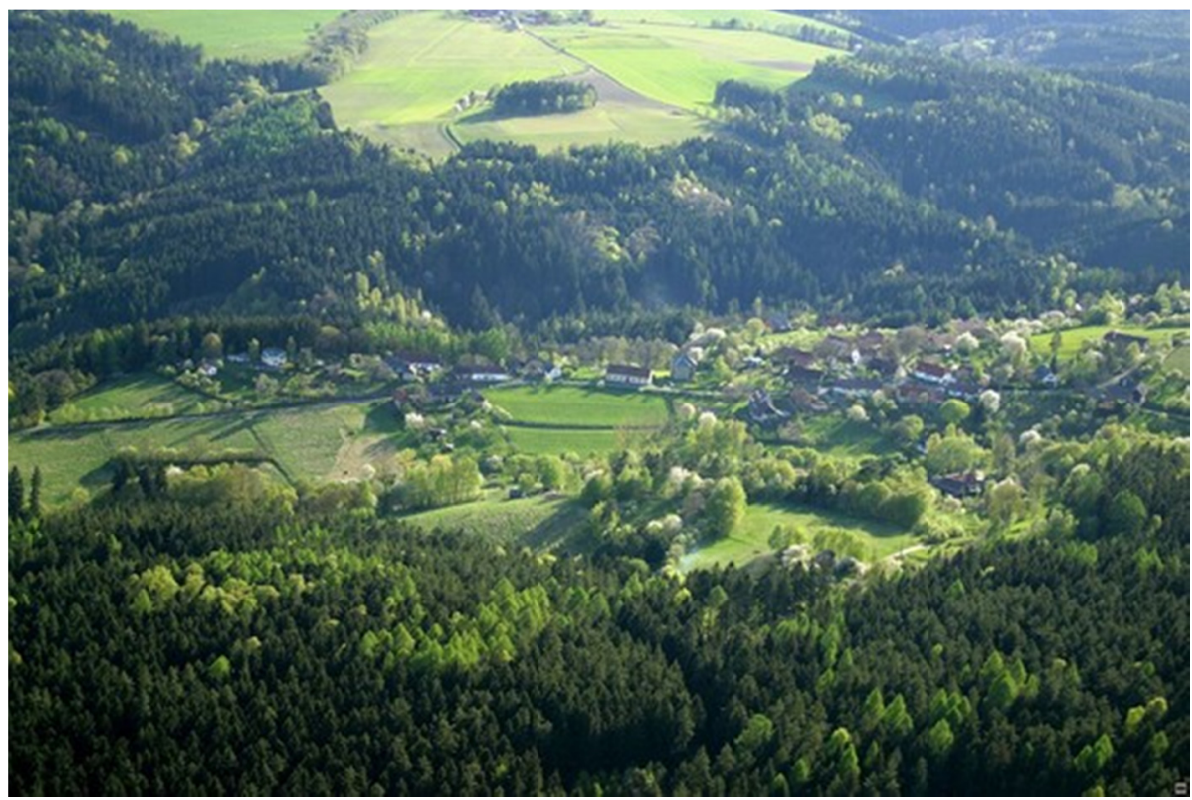

Figure 2. Aerial photo of the settlement of Budín. The photograph shows the current condition of the landscape. (Source: Samopše village)

The inventory of woody plants (Table 3 ) in existing non-forest woody vegetation elements show that $93 \%$ of the scattered greenery type was vegetation surrounding the Sázava River, $6 \%$ consisted of a more extensive belt of vegetation in the open landscape and the remaining $1 \%$ consisted of vegetation along the local service road. Nine segments of landscape vegetation were defined, with a high proportion of line and blanket elements, supplemented by clusters of trees and solitary specimens along the watercourse. The low percentage of scattered greenery is mostly the result of the high recreational potential of this area and the demarcation of this area by forest growth.

The total area of non-forest woody vegetation elements in the Budín settlement is $36,365 \mathrm{~m}^{2}$, which forms $2.6 \%$ of the total area of the examined settlement and corresponds to $1 \mathrm{~m}^{2}$ of scattered greenery per approx. $35.69 \mathrm{~m}^{2}$ of the total area.

Seventeen species of deciduous tree were identified in the open landscape of the model territory (Table 3). The predominant species are Common Plum (Prunus domestica ssp. L.), Blackthorn (Prunus spinosa ssp. L.) and Common Hazel (Corylus avellana L.). Growth is dominated by European Beech (Fagus syslvatica L.), European Hornbeam (Carpinus betulus L.), European Ash (Fraxinus excelsior L.) and Field Maple (Acer campestre L.). In elements of scattered greenery surrounding the Sázava River, the predominant species are Basket Willow (Salix viminalis L.), Goat Willow (Salix caprea L.) and White Willow (Salix alba L.), with some Common Alder (Alnus glutinosa L.). The extensive number of species in individual areas of growth increases the diversity of the landscape character.

Statistical analysis shows that the evaluated vitality of growth in the Budín settlement was very good. The values show that $77.8 \%$ of the total volume of non-forest woody vegetation elements are classified in category A and B. These are woody plants of high vitality and plantation value. This aspect is favourable, particularly in relation to the preservation of the existing landscape character, but $22.2 \%$ are elements classified in category C and D, old or damaged woody plants, reasonably typical of the specific area of interest, but with low plantation value. It is statistically shown that an above-half majority $(66.7 \%)$ of the non-forest woody vegetation elements correspond to the characteristics arising from the Map of Potentially Natural Vegetation (Neuhäuslová et al., 1998). The composition of vegetation elements therefore demonstrates the suitability of the current growth in this landscape character and the defined regional ecological stability composition areas (ÚSES). 
Table 3. Inventory of woody plants in individual elements of non-forest woody vegetation and elements of non-forest woody vegetation at the Budín settlement. (Source: author's elaboration).

\begin{tabular}{|c|c|c|c|c|c|c|c|c|c|c|}
\hline \multirow{2}{*}{$\begin{array}{c}\text { Type of } \\
\text { vegetation }\end{array}$} & \multirow[t]{2}{*}{$\operatorname{Area}\left(\mathbf{m}^{2}\right)$} & \multirow{2}{*}{ Range of vegetation } & \multicolumn{4}{|c|}{$\begin{array}{c}\text { Evaluation of } \\
\text { vitality }\end{array}$} & \multicolumn{4}{|c|}{$\begin{array}{c}\text { Evaluation of } \\
\text { suitability }\end{array}$} \\
\hline & & & $\mathbf{A}$ & B & $\mathbf{C}$ & D & $\mathbf{a}$ & b & c & d \\
\hline Field border & $311 \mathrm{~m}^{2}$ & $\begin{array}{l}\text { Carpinus betulus L., Fagus sylvatica L., Fraxinus excelsior L., Rosa canina } \\
\text { L., Sambucus nigra L.. } \\
\text { Rhamnus cathartica L. Euonymus europaeus L., Betula pendula Roth., Rosa } \\
\text { canina L., }\end{array}$ & $\mathrm{x}$ & $\mathrm{x}$ & & & & $\mathrm{x}$ & & \\
\hline $\begin{array}{l}\text { Vegetation } \\
\text { along the }\end{array}$ & $1,562 \mathrm{~m}^{2}$ & $\begin{array}{l}\text { Prunus spinosa ssp. L., Prunus domestica ssp. L., Rosa canina L., Sambucus } \\
\text { nigra L., }\end{array}$ & & $\mathrm{x}$ & & & & & $\mathrm{x}$ & \\
\hline local road & & Euonymus europaeus L., Prunus spinosa ssp. L., & & $\mathrm{x}$ & & & & & $\mathrm{x}$ & \\
\hline $\begin{array}{l}\text { Vegetation } \\
\text { along the } \\
\text { watercourse }\end{array}$ & $20,000 \mathrm{~m}^{2}$ & $\begin{array}{l}\text { Salix alba L., Salix viminalis L., Salix caprea } \mathrm{L} ., \text { Alnus glutinosa } \mathrm{L} \text {. } \\
\text { Fraxinus excelsior L., Corylus avellana L., Salix alba L., } \\
\text { Alnus glutinosa L., Alnus incana L., Salix alba L., }\end{array}$ & $\begin{array}{l}\mathrm{x} \\
\mathrm{x}\end{array}$ & $x$ & & & $\begin{array}{l}x \\
x \\
x\end{array}$ & & & \\
\hline Cluster & $4,086 \mathrm{~m}^{2}$ & $\begin{array}{l}\text { Salix alba L., Salix caprea L., Rosa canina } \mathrm{L} ., \\
\text { Salix caprea } \mathrm{L} ., \text { Alnus glutinosa L., Salix alba L., }\end{array}$ & & $\mathrm{x}$ & $\mathrm{x}$ & & $\begin{array}{l}\mathrm{x} \\
\mathrm{x}\end{array}$ & & & \\
\hline Belt & $10,000 \mathrm{~m}^{2}$ & $\begin{array}{l}\text { Acer campestre L, Fraxinus excelsior L., Betula pendula Roth., Sorbus } \\
\text { aucuparia L., Prunus spinosa ssp. L., } \\
\text { Sambucus nigra L., Betula pendula Roth., Prunus spinosa ssp. L., } \\
\text { Euonymus europaeus L.,Rosa canina L., } \\
\text { Carpinus betulus L., Betula pendula Roth., Prunus spinosa ssp. L., Rhamnus } \\
\text { cathartica L., }\end{array}$ & $\mathrm{x}$ & $\mathrm{x}$ & & & & $\mathrm{x}$ & $\mathrm{x}$ & \\
\hline Group & $21 \mathrm{~m}^{2}$ & Salix alba L., Alnus glutinosa $\mathrm{L}$. , & $\mathrm{x}$ & & & & $\mathrm{x}$ & & & \\
\hline Group & $267 \mathrm{~m}^{2}$ & Salix alba L., Salix caprea L., & $\mathrm{x}$ & & & & $\mathrm{x}$ & & & \\
\hline Group & $50 \mathrm{~m}^{2}$ & Salix caprea L., Alnus glutinosa L., Salix alba L., & & $\mathrm{x}$ & & & $\mathrm{x}$ & & & \\
\hline Group & $68 m^{2}$ & Alnus glutinosa L., Salix alba L., Populus alba L. & & & & $\mathrm{x}$ & $\mathrm{x}$ & & & \\
\hline
\end{tabular}

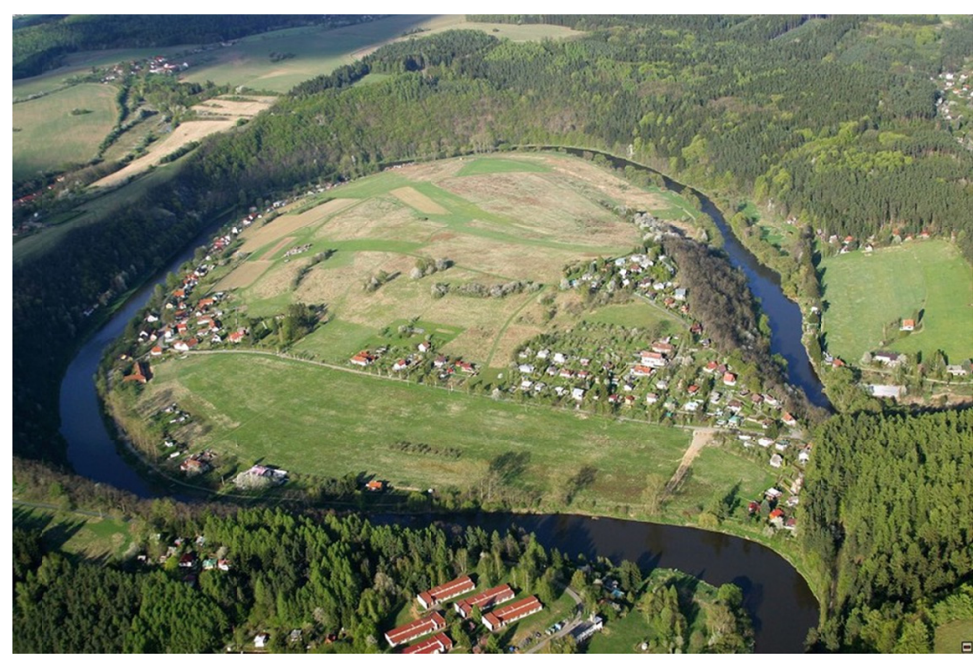

Figure 3. Aerial photograph of the Prŕvlaky settlement. The photograph shows the current state of the deeply valleyed landscape. (Source: Samopše village)

\subsection{Př́lVlaky Settlement}

The settlement of Př́vlaky is located in the southern area of the village of Samopše. The Sázava River is outside the boundaries of the model area (Fig. 3) and surrounds the entire settlement, creating a characteristic meander, the so-called "Př́vlacká mušle". The total defined area of the settlement is $900,000 \mathrm{~m}^{2}$. The Prrívlaky landscape is defined as a landscape of deep valleys, described by Löw \& Novák (2006) as "deep valleys of rivers and their tributaries, usually forested, frequently with the presence of cliff promontories on slopes and their upper edges. A landscape with high topographical relief dynamics and with high natural value" (Vondra Krupková, 2018). 
Thirteen extensive and scattered non-forest woody vegetation elements were recorded at the Přívlaky settlement, located in the open landscape. The total area of scattered greenery in this settlement is $42,849 \mathrm{~m}^{2}$ (i.e., $4.76 \%$ of the total area of the territory), with $43 \%$ of the elements present as line structures of scattered greenery, $38 \%$ as blanket elements and $15 \%$ as spot elements in the form of solitary specimens.

\section{The total area of non-forest woody vegetation elements in the Př́vlaky settlement is $42,849 \mathrm{~m}^{2}$, which forms $4.76 \%$ of the total area and corresponds to $1 \mathrm{~m}^{2}$ of scattered greenery per approx. $17.22 \mathrm{~m}^{2}$ of the total area.}

The inventory gathered and field survey (Table 4) confirmed the theoretical findings of the composition of vegetation in the area examined, which should correspond to the characteristics found in the Map of Potentially Natural Vegetation (Neuhäuslová et al., 1998), whereas the vegetation surrounding the watercourse corresponds to locations with wetter conditions, the vegetation near the settlement (birch avenues) represents human influence (intentional planting) and the species composition of scattered greenery in the landscape corresponds to the origin of the specific element (retreating forest, spontaneous spreading and human intervention in the form of artificial planting and additional planting). The dominant species in the scattered greenery growth is Blackthorn (Prunus spinosa ssp. L.), with a $19 \%$ occurrence of all types of scattered greenery types. The second and third most frequent species are Silver Birch (Betula pendula L.) and Common Plum (Prunus domestica ssp. L.). In the area surrounding the watercourse, the most frequent species are White Willow (Salix alba L.) and Common Alder (Alnus glutinosa L.). Thermophilic Cornelian Cherry (Cornus mas L.) occasionally appears in some non-forest woody vegetation elements.

Table 4. Inventory of woody plants in individual non-forest woody vegetation elements at the Prrívlaky settlement. (Source: author's elaboration)

\begin{tabular}{|c|c|c|c|c|c|c|c|c|c|c|}
\hline \multirow{2}{*}{$\begin{array}{c}\text { Type of } \\
\text { vegetation }\end{array}$} & \multirow{2}{*}{$\begin{array}{l}\text { Area } \\
\left(\mathbf{m}^{2}\right)\end{array}$} & \multirow[t]{2}{*}{ Range of vegetation } & \multicolumn{4}{|c|}{$\begin{array}{l}\text { Assessment of } \\
\text { vitality }\end{array}$} & \multicolumn{4}{|c|}{$\begin{array}{c}\text { Assessment of } \\
\text { suitability }\end{array}$} \\
\hline & & & $\mathbf{A}$ & B & $\mathrm{C}$ & D & $\mathbf{a}$ & $\mathbf{b}$ & c & d \\
\hline $\begin{array}{l}\text { Solitary } \\
\text { specimen }\end{array}$ & $22 \mathrm{~m}^{2}$ & Acer campestre L.,Betula pendula Roth., & & $\mathrm{x}$ & & & & & $\mathrm{x}$ & \\
\hline Field border & $1753 m^{2}$ & $\begin{array}{l}\text { Fraxinus excelsior L., Quercus robur L., Corylus avellana L., Rosa canina L. } \\
\text { Sambucus nigra L., Fraxinus excelsior L., Betula pendula L., Prunus spinosa ssp. } \\
\text { L., Prunus domestica ssp. L., }\end{array}$ & $\mathrm{x}$ & & $\mathrm{x}$ & & & $\mathrm{x}$ & $\mathrm{x}$ & \\
\hline Field border & $1224 \mathrm{~m}^{2}$ & $\begin{array}{l}\text { Quercus robur L., Crataegus monogyna Jack., Euonymus europaeus L., } \\
\text { Betula pendula Roth., Picea abies L., Fraxinus excelsior L., Rosa canina L., } \\
\text { Sambucus nigra L., }\end{array}$ & $\mathrm{x}$ & $\mathrm{x}$ & & & & $\mathrm{x}$ & & \\
\hline Field border & $2687 \mathrm{~m}^{2}$ & $\begin{array}{l}\text { Prunus domestica ssp. L., Crataegus monogyna Jack., Rosa canina L., Sambucus } \\
\text { nigra L. } \\
\text { Betula pendula Roth., Fraxinus excelsior L., Corylus avella L., Rhamnus } \\
\text { cathartica L., Euonymus europaeus L. }\end{array}$ & $\mathrm{x}$ & $\mathrm{x}$ & & & $\mathrm{x}$ & & $\mathrm{x}$ & \\
\hline Group & $375 m^{2}$ & $\begin{array}{l}\text { Prunus domestica ssp. L., Prunus spinosa ssp. L., Rosa canina L., Sambucus } \\
\text { nigra L. }\end{array}$ & & $\mathrm{x}$ & & & & & $\mathrm{x}$ & \\
\hline Cluster & $376 m^{2}$ & $\begin{array}{l}\text { Fraxinus excelsior L., Punus spinosa ssp. L., Malus domestica ssp. L., } \\
\text { Prunus domestica ssp. L., Pyrus communis ssp. L., Rosa canina L., Euonymus } \\
\text { europaesu L., }\end{array}$ & & $\mathrm{x}$ & $\mathrm{x}$ & & & & $\mathrm{x}$ & $\mathrm{x}$ \\
\hline Cluster & $846 m^{2}$ & $\begin{array}{l}\text { Prunus doemestica ssp. L., Prunus spinosa ssp. L., Rosa canina L., Sambucus } \\
\text { nigra L., Cornus mas L., }\end{array}$ & & $\mathrm{x}$ & & & & & $\mathrm{x}$ & \\
\hline & & Fraxinus excelsior L., Malus domestica ssp. L., Pyrus communis ssp. L. & & $\mathrm{x}$ & & & & & $\mathrm{x}$ & \\
\hline Avenue & $1796 \mathrm{~m}^{2}$ & Betula pendula Roth., Sorbus aucuparia L. & $\mathrm{x}$ & & & & $\mathrm{x}$ & & & \\
\hline $\begin{array}{l}\text { Vegetation } \\
\text { along } \\
\text { watercourse }\end{array}$ & $28408 m^{2}$ & $\begin{array}{l}\text { Salix alba L., Alnus glutinosa L., Salix caprea L., Corylus avellana L., } \\
\text { Salix viminalis L., Populus tremula L., Salix alba L., Salix caprea L., } \\
\text { Salix alba L., Alnus glutinosa L., Populus tremula L. } \\
\text { Alnus glutinosa L., Salix viminalis L., Salix caprea L. }\end{array}$ & $\mathrm{x}$ & & & & $\mathrm{x}$ & & & \\
\hline Group & $225 \mathrm{~m}^{2}$ & $\begin{array}{l}\text { Betula pendula Roth., Carpinus betulus L., Prunus domestica ssp. L., Prunus } \\
\text { spinosa } \text { ssp. L.,Fagus syslatica L., }\end{array}$ & & $\mathrm{x}$ & & & & & $\mathrm{x}$ & \\
\hline Belt & $2789 m^{2}$ & $\begin{array}{l}\text { Acer campetre L., Betula pendula Roth., Prunus spinosa ssp. L., Carpinus betulus } \\
\text { L., Crataegus monogyna Jack., }\end{array}$ & $\mathrm{x}$ & & & & & $\mathrm{x}$ & & \\
\hline Grove & $2337 \mathrm{~m}^{2}$ & $\begin{array}{l}\text { Prunus spinosa ssp. L., Malus domesica ssp. L., Betula pedula Roth., Euonymus } \\
\text { europaeus L., Rosa canina L., Prunus domestica ssp. L., }\end{array}$ & $\mathrm{x}$ & & & & $\mathrm{x}$ & & & \\
\hline $\begin{array}{l}\text { Solitary } \\
\text { specimen }\end{array}$ & $11 \mathrm{~m}^{2}$ & Betula pendula Roth. & & $\mathrm{x}$ & & & & $\mathrm{x}$ & & \\
\hline
\end{tabular}


The values show that $85 \%$ of the total 13 vegetation elements are classified as category A and B. This indicates vital woody plants with long-term existence and higher plantation value. Older and old specimens and growth appear in this element and form the skeleton of the specific vegetation element, their long-term existence conditional on regular maintenance and interventions in growth. It is statistically shown that an above-half majority $(66.7 \%)$ of the vegetation elements of non-forest woody vegetation corresponds to the characteristics arising from the Map of Potentially Natural Vegetation (Neuhäuslová et al., 1998). The composition of vegetation elements therefore demonstrates the suitability of the current growth in this landscape character and the defined regional ecological stability system composition areas (ÚSES).

\subsection{Talmberk Settlement}

The boundaries of the Talmberk settlement (Fig. 4) adjoin the boundaries defining the Mrchojedy settlement and consist of forest and the cadastral boundary of the municipality in the north-western, northern and north-eastern area. The total area of the settlement is $680,000 \mathrm{~m}^{2}$. "The presence of areas covered in woody vegetation ranges between $10 \%$ and $70 \%$. The landscape has a mostly semi-open character" (Löw \& Novák, 2006; Vondra Krupková, 2018).

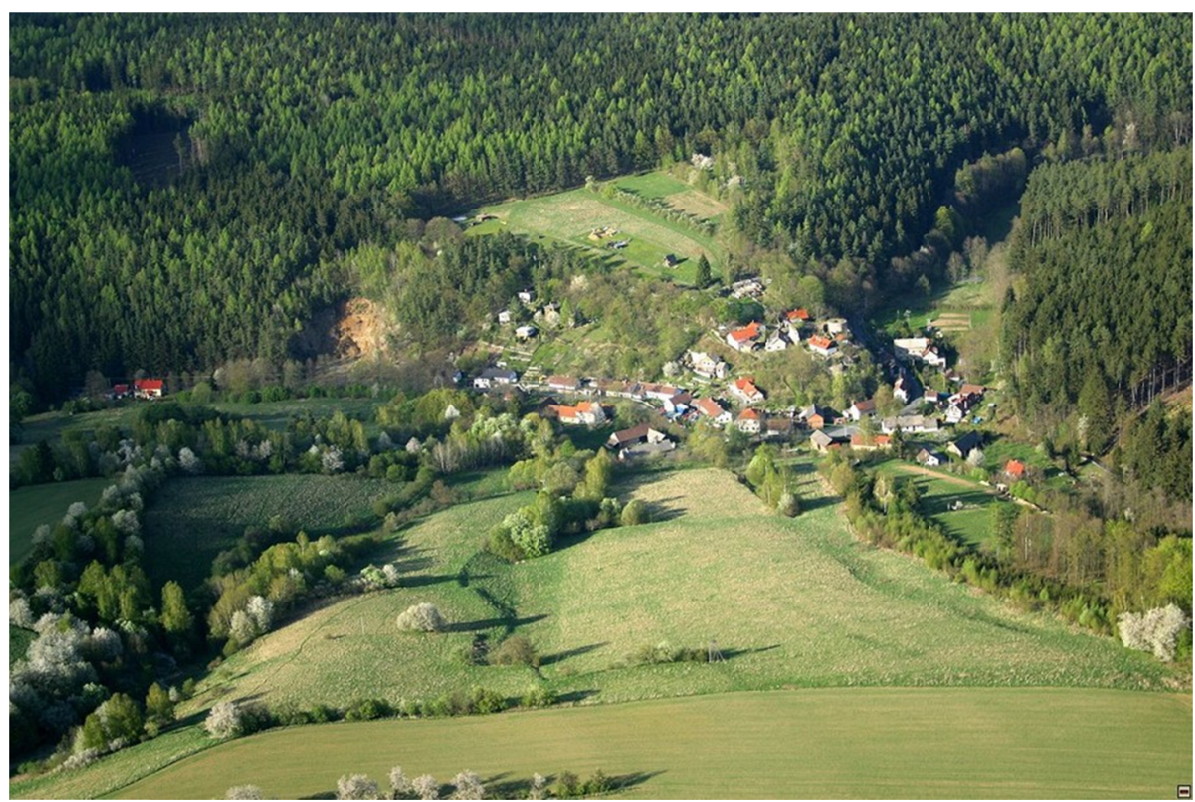

Figure 4. Aerial photograph of the Talmberk settlement. The photograph shows the current condition of the forest landscape. (Source: Samopše village)

Eleven landscape vegetation elements were identified (Table 5 ) at the Talmberk settlement, arranged outside the developed village area, with $46 \%$ consisting of line elements (field borders, belts, strips) of scattered greenery, $36 \%$ of blanket elements (clusters) and $18 \%$ of spot elements in the form of solitary specimens. The vegetation around the Talmberk/Úžice stream, which flows through the Talmberk settlement from the northeast through the centre of the settlement and to the north-western boundary, creates a significant element of greenery. The stream is surrounded by typical hydrophilic communities of species of trees, bushes and herbs.

\footnotetext{
The total area of non-forest woody vegetation elements in the Talmberk settlement is $7838 \mathbf{~ m}^{2}$, which forms $1.15 \%$ of the total area of the examined settlement and corresponds to $1 \mathrm{~m}^{2}$ of scattered greenery per approx. $44.71 \mathrm{~m}^{2}$ of the total area.
}

The inventory gathered (Table 5) was the basis for determining the percentage of species of individual types of non-forest woody vegetation. Of the total number (11) evaluated, the following species were most frequently present in growth: Silver Birch (Betula pendula Roth.), Common Plum (Prunus domestica ssp. L.) and European Ash (Fraxinus excelsior L.). Common Alder (Alnus glutinosa L.) and White Willow (Salix alba L.) appears in the area surrounding the Talmberk/Úžice stream most frequently. Growth also occasionally includes fruit species such as Orchard Apple (Malus domestica ssp. L.), European Pear (Pyrus communis ssp. L.,) and Sweet Cherry (Prunus avium ssp. L.). The presence of these species is the result of fruit trees planted in 1930-1939. Only 
solitary specimens of tree and bush were assessed as single-species vegetation elements. The composition of woody vegetation elements does not correspond to the content of the Map of Potential Natural Vegetation (Neuhäuslová et al., 1998).

Table 5. Inventory of woody plants in individual elements of non-forest woody vegetation at the Talmberk settlement. (Source: author's elaboration)

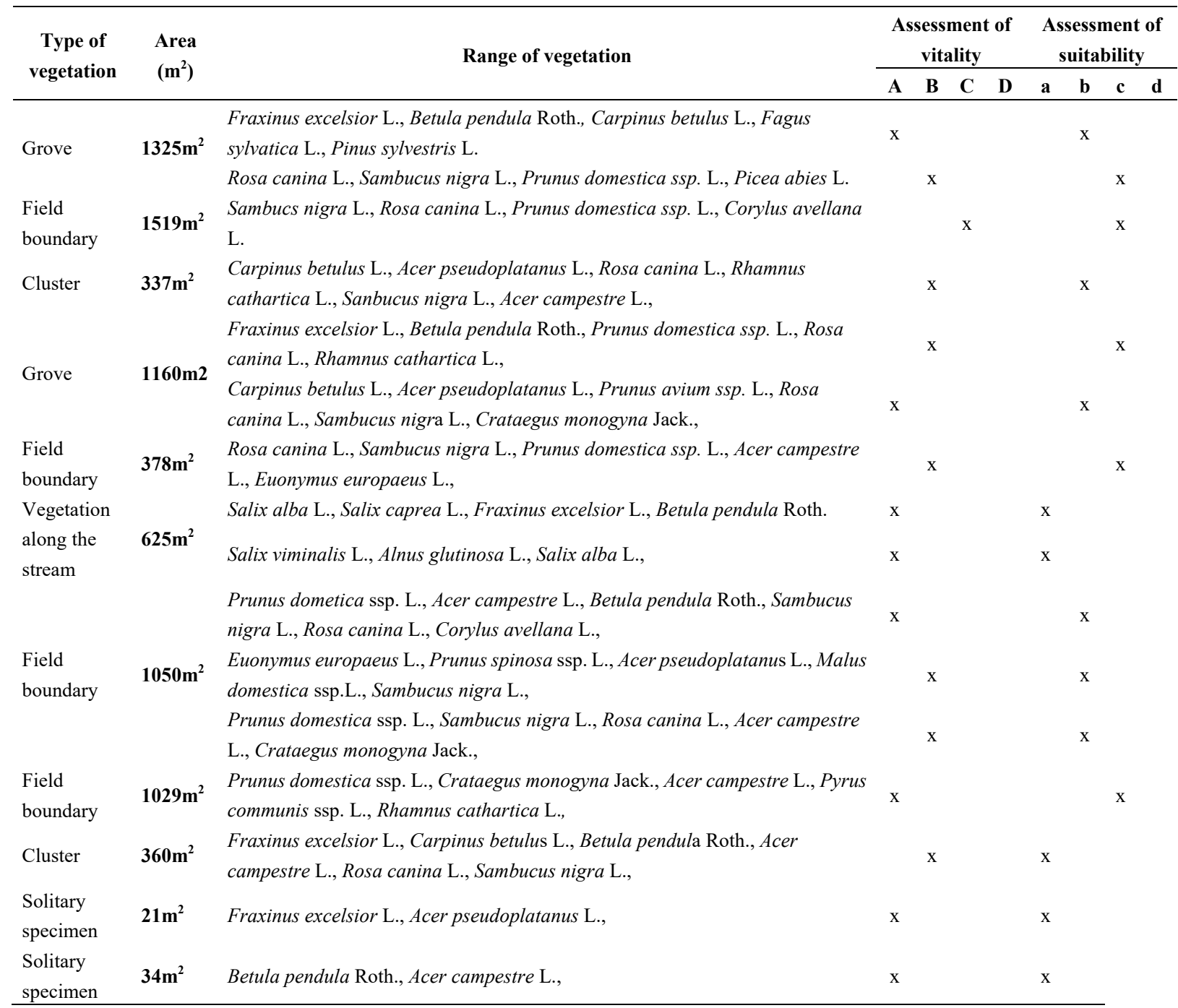

Statistical assessment shows that the assessed vitality of growth was mostly very good (Table 5). The values show that of the total number of inventoried segments of individual elements of non-forest woody vegetation, 15 segments $(94 \%)$ are classified as category A and B, which are healthy and vital woody plants with long-term prospects for the future. This condition is favourable for the preservation of the current elements of non-forest woody vegetation, landscape character and appearance. Only one vegetation element $(6 \%)$ of the total value has low vitality and plantation value. No vegetation elements were classified as type D under the assessment criteria.

\subsection{Mrchojedy Settlement}

The boundaries of the Mrchojedy settlement (Fig. 5) adjoin the defined boundaries of the settlement of Budin in the north-western section of the cadastral area. The total area of the settlement is $1,798,435 \mathrm{~m}^{2}$. An agricultural landscape is typical of the Mrchojedy settlement. Löw \& Novák (2006) describe this type as a landscape strongly affected by human cultivation. Forests cover less than $10 \%$ of this area, and $90 \%$ is agricultural land consisting of fields and permanent grassland. The landscape has a visually open character. 


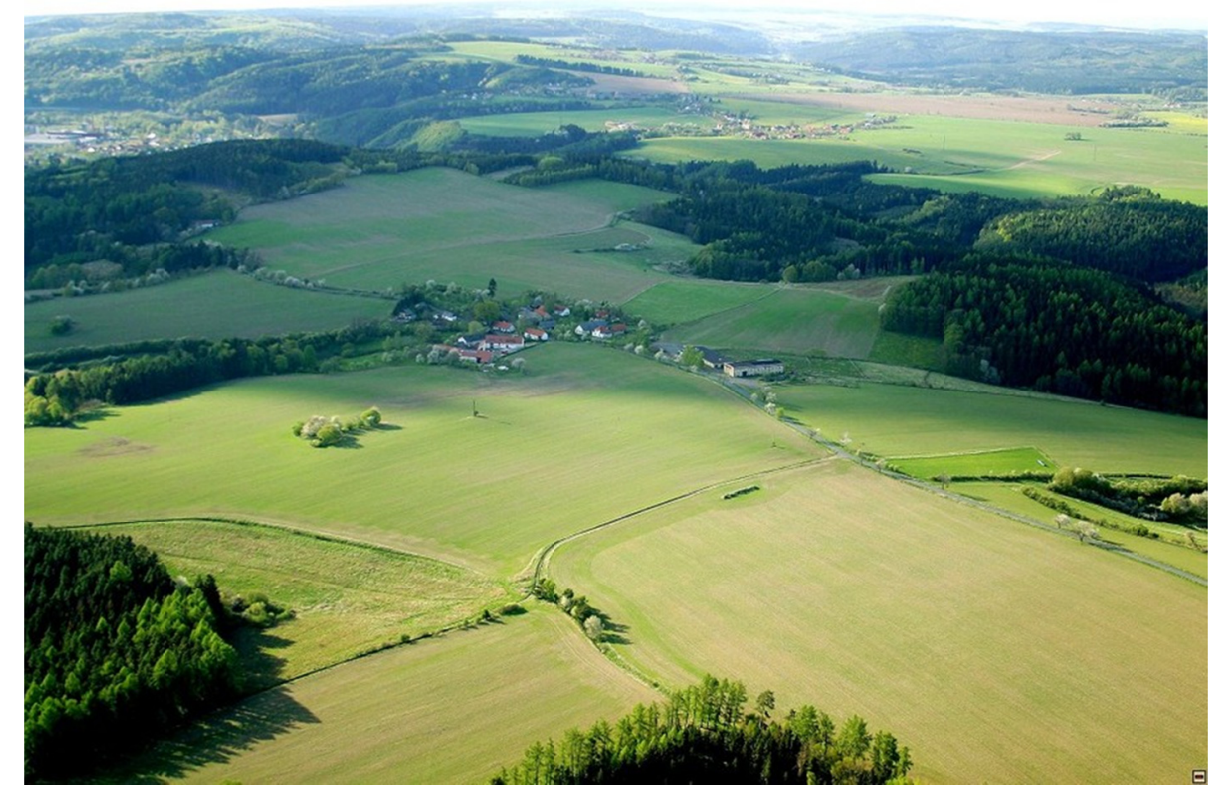

Figure 5. Aerial photo of the Mrchojedy settlement. This photograph shows the current state of the forest landscape. (Source: Samopše village)

Thirteen extensive landscape vegetation elements outside the developed area were inventoried (Table 6), with $47 \%$ of scattered greenery consisting of line elements (field borders and belts), $39 \%$ of blanket elements in clusters and $7 \%$ of the land covered by vegetation surrounding roads (cherry tree avenues). The accompanying line of vegetation surrounding the Samopše Stream is one vegetation element and covers $7 \%$. The total area of non-forest woody vegetation is $13,854 \mathrm{~m}^{2}(0.77 \%)$ of the total area of $1,798,435 \mathrm{~m}^{2}$.

\section{The total area of the non-forest woody vegetation elements in the Mrchojedy settlement is $42,849 \mathrm{~m}^{2}$, which forms $4.76 \%$ of the total area and corresponds to $1 \mathrm{~m}^{2}$ of scattered greenery per approx. $17.22 \mathrm{~m}^{2}$ of the total area.}

The main type of growth of scattered greenery in the open landscape of Mrchojedy is Common Plum (Prunus domestica ssp. L.), Common Hazel (Corylus avellana L.) and European Ash (Fraxinus excelsior L.). An important element of the scattered greenery is the Cherry (Prunus avium ssp. L.) avenue on both sides of the local service road. The dominant species of vegetation surrounding the Samopše Stream are White Willow (Salix alba L.) and Common Alder (Alnus glutinosa L.). Species of coniferous trees also appear in the non-forest woody vegetation cover, $8 \%$ being Scots Pine (Pinus syslvestris L.). Self-seeding woody plants include European Elderberry (Sambucus nigra L.) and Dog Rose (Rosa canina L.), with some varieties of European Spindle (Euonymus europaeus L.) and Buckthorn (Rhamnus cathartica L.).

Statistical evaluation shows that the assessed vitality of growth was mostly very good. The values show that 11 out of the total 13 vegetation elements (84\%) were classified in category A and B. This indicates healthy woody plants with high vitality and plantation value. This aspect is favourable, particularly for preservation of the current landscape character and its appearance. Two $(16 \%)$ vegetation elements have low vitality and plantation value. No vegetation elements were classified as type D under the assessment conditions. The composition of woody plants in vegetation elements does not fully correspond to the context of the Map of Potentially Natural Vegetation (Neuhäuslová et al., 1998). 
Table 6. Inventory of woody plants in individual non-forest woody vegetation elements at the Mrchojedy settlement. (Source: author's elaboration)

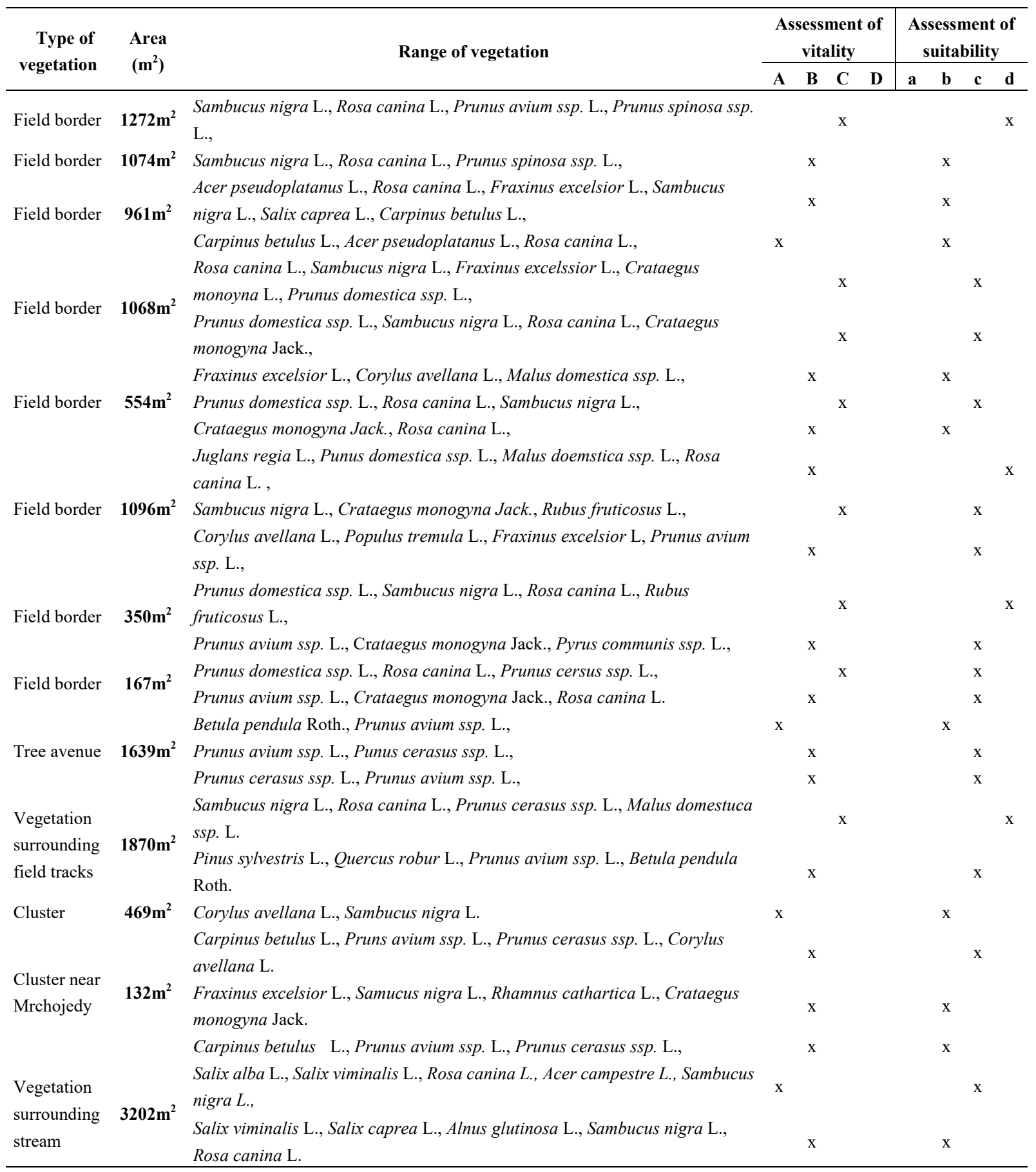

\subsection{Samop̌̌e Settlement}

The total area of this settlement is 2,524,000 $\mathrm{m}^{2}$. The settlement of Samopše (Fig. 6) is an exemplary "forest-agricultural landscape" type, "which is a harmonious rural landscape with varied presence of "soft" forms of topographical relief and methods of use of the area. Communities of smaller copses, field boundaries, bank growth along streams and areas of secondary grassland, mostly almost natural, and various methods of use of the area typically appear to a great degree, also due to the varied topographical relief. These are of a semi-open character" (Löw \& Novák, 2006). 


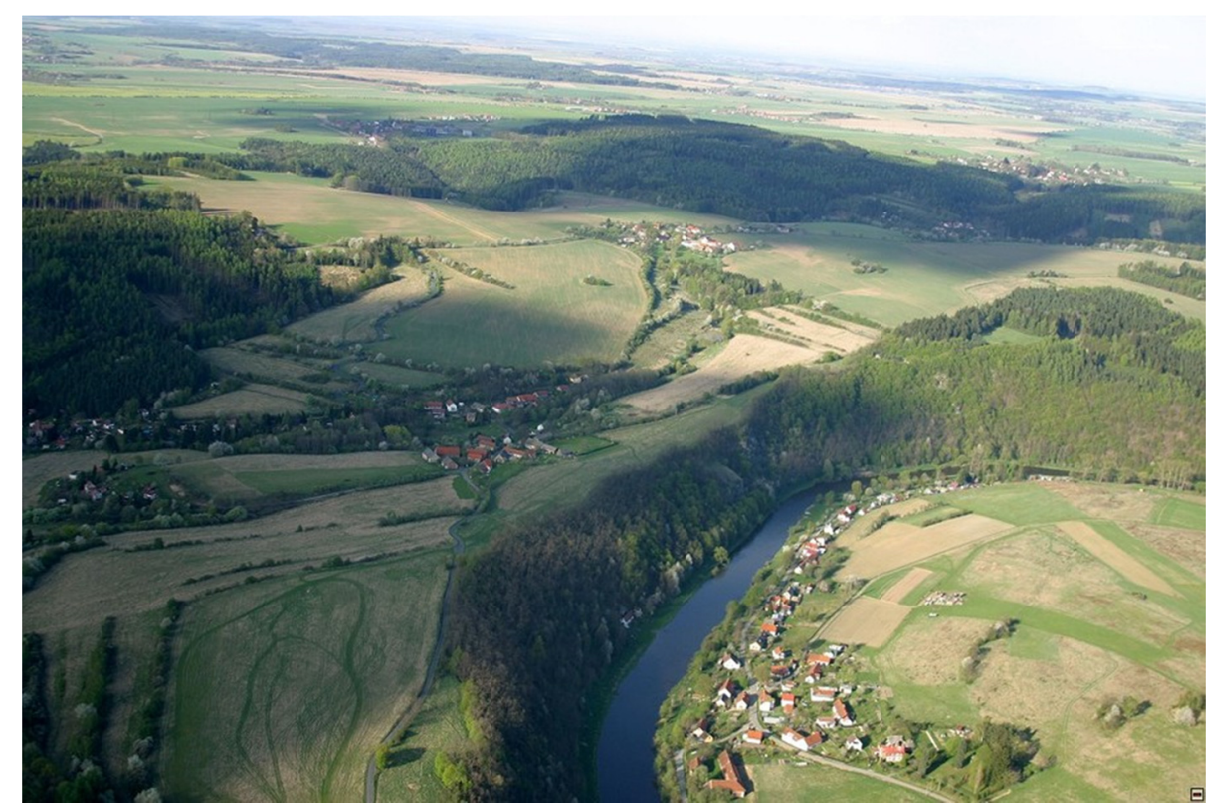

Figure 6. Aerial photograph of the Samopše settlement. The photograph shows the current state of the forest landscape. (Source: Samopše village)

Thirty-three non-forest woody vegetation elements were identified in the defined area (Table 7), which includes field boundaries $(61 \%)$, clusters, vegetation surrounding local roads, watercourses and areas, and five solitary specimens. The total area of non-forest woody vegetation is $73,928 \mathrm{~m}^{2}$ (2.92\% of the total area).

The total area of elements of non-forest woody vegetation in the Samopše settlement is $73,928 \mathbf{~ m}^{2}$, which forms $2.92 \%$ of the total area and corresponds to $1 \mathrm{~m}^{2}$ of scattered greenery per approx. $26.37 \mathrm{~m}^{2}$ of the total area.

Thirty-nine elements were inventoried at the Samopše settlement, divided into 112 segments of landscape vegetation outside the developed area of the village, where nearly $62 \%$ of the scattered vegetation type is field boundaries, $10 \%$ is solitary specimens, $8 \%$ consists of vegetation surrounding watercourses and areas, $8 \%$ is clusters, $10 \%$ is vegetation surrounding roads and $2 \%$ is groups of trees located in fields.

The dominant species in the scattered greenery of this landscape are Blackthorn (Prunus spinosa ssp. L.), Common Plum (Prunus domestica ssp. L.) and Silver Birch (Betula pendula Roth.). Non-forest woody vegetation growth contains significant numbers of Common Hawthorn (Crataegus monogyna Jack.) and Buckthorn (Rhamus cathartica L.) compared to the species composition of the other settlements. The Samopše settlement is the only settlement to contain rare specimens of a variety of Cornelian Cherry (Cornus mas L.). In the area surrounding the watercourse, the dominant species are White Willow (Salix alba L.), Basket Willow (Salix viminalis L.), Common Alder (Alnus glutinosa L.) and European Aspen (Populus tremula L.). The dominant species in the area surrounding the local service road is Sweet Cherry (Prunus avium ssp. L.), which runs along both sides of the road as an avenue. By contrast, Black Locust (Robinia pseudoacacia L.) and European Ash (Fraxinus excelsior L.) grow along roads in the southern part of the area.

Statistical assessment shows that the assessed vitality of growth was mostly very good. The values show that 26 out of the 39 vegetation elements (i.e., $66 \%$ of all non-forest woody vegetation growth) are classified in categories A and B. Ten (26\%) of the vegetation elements are of lower vitality and plantation value. Only one third $(31 \%)$ of scattered greenery vegetation elements corresponds to the context of the Map of Potentially Natural Vegetation (Neuhäuslová et al., 1998). 
Table 7. Inventory of woody plants in individual elements of non-forest woody vegetation at the settlement of Samopše. (Source: author's elaboration)

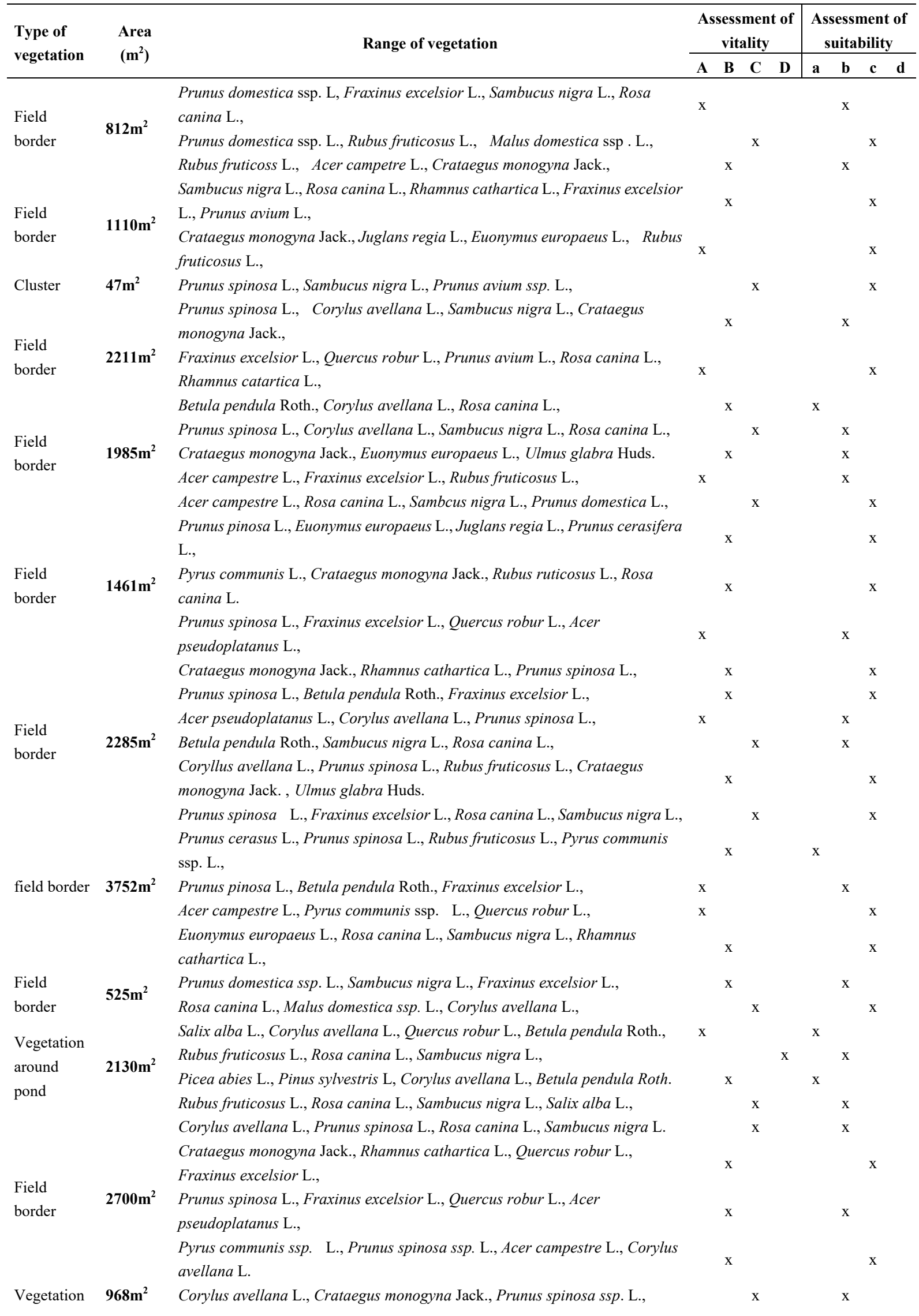


Rosa canina L.

below the pond dam (Samopše

Stream)

Field

border

Field

border

Field

border

Field

border

Sunken

lane

Cluster

Field

border

Field

border

Cluster
Sambucus nigra L., Prunus cerasus ssp. L., Populus tremula L.,

Robinia pseudoacacia L., Salix alba L.,

$\mathrm{X}$

Corylus avellana L., Prunus spinosa ssp. L., Rosa canina L., Crataegus monogyna Jack., Prunus aviumssp.L.,

$\mathbf{1 5 5 6 m}^{2}$ Roa canina L., Prunus spinosa ssp. L., Rhamnus cathartica L.,

Prunus spinosa ssp. L., Crataegus monogyna Jack., Quercus robur L., Rosa canina L., Malus domestica ssp. L.,

Prunus spinosa ssp. L., Faxinus excelsior L.,Prunus avium ssp. L.,

Carpinus betulus L., Crataegus monogyna Jack., Corylus avellana L.,

Rosa canina L., Sambucus nigra L., Corylus avellana L., Prunus avium ssp. L.

Rubus fruticous L, Prunus spinosa ssp. L., Corylus avellana L., Rhamnus

cathartica L.,

Clematis vitalba L., Sambucus nigra L., Acer campstre L., Rosa canina L.,

Prunus spinosa ssp. L.,

Prunus spinosa ssp. L., Crataegus monogyna Jack., Rosa canina L., Euonymus europaeus L.,

Quercus petrae L., Prunus spinosa ssp. L., Prunus avium L., Rubus frutiosus

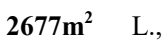

Prunus spinosa ssp. L., Crataegus monogyna Jack., Rosa canina L., Euonymus europaeus L., Ulmus glabra Huds.,

Carpinus betulus L., Ulmus glabra Huds., Sambucus nigra L.

Carpinus betulus L., Quercus robur L., Acer campestre L., Prunus spinosa ssp. L.,

Robinia pseudoacacia L., Punus spinosa ssp. L., Sambucus nigra L.,

$\mathbf{1 6 8 7} \mathbf{m}^{2}$ Crataegus monogyna Jack.,

Rubus fruticosus L., Corylus avellana L., Prunus spinosa ssp. L., Quercus robur L., Prunus avium ssp. L.,

Prunus spinosa ssp. L., Rosa canina L., Carpinus betulus L.,

Fraxinus excelsior L., Prunus domestca ssp. L., Acer campestre L., Rosa canina L.,

$\mathbf{1 3 2 5 m}^{2}$ Betula pendula Roth., Acer campestre L., Rosa canina L., Crataegus

monogyna Jack., Citisus praecox L., Ligustrum vulgare L.,

Humulus lupulus L., Prunus sinosa ssp. L., Rosa canina L.,

Carpinus betulus L:, Pruns avium ssp. L., Prunus cerasus ssp. L., Corylus

avellana L.,

$372 \mathbf{m}^{2}$

Fraxinus excelsior L., Samucus nigra L., Rhamnus cathartica L., Crataegus

monogyna Jack.,

Carpinus betulus L., Prunus avium ssp. L., Prunus cerasus ssp. L.,

Carpinus betulus L., Crataegus monogyna Jack., Euonymus europaeus L.,

Rhamnus cathartica L.,

$755 \mathrm{~m}^{2}$

Sambucus nigra L. Prunus avium ssp. L., Corylus avellana L., Rosa canina L., Prunus spinosa ssp. L.,

Rosa canina L., Prunus spinosa ssp. L., Ruus fruticosus L., Crataegus

monogyna Jack.

Prunus cerasus ssp. L., Rhamnus cathartica L., Prunus spinosa ssp.L., Rosa

canina L.

$\mathbf{1 1 1 0 m}^{2}$ Clematis vitalba L., Rosa cania L., Sambucus nigra L., Prunus spinosa ssp. L., Quercus robur L., Rosa canina L., Prunus avium ssp.L., Crataegus monogyna Jac.,

Fraxinus excelsior L, Prunus avium ssp. L., Rosa canina L., Sambucus nigra L.

$1240 \mathrm{~m}^{2} \quad s s p . \mathrm{L}$.

Rubus fruticosus L., Rosa canina L., Fraxinus excelsior L., Prunus spinosa

Rhamnus cathartica L., Rosa canina L., Prunus avium ssp. L., Prunus spinosa
$\mathrm{X}$

$\mathrm{X}$

$\mathrm{x}$

X

$\mathrm{x}$

X

X

X

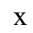

$\mathrm{x}$

X

X

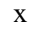

$\mathrm{X}$

$\mathrm{X}$

X

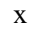

X

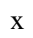

X

X

X X 
Field

border

Field

border

Field

border

Field

border

Field

border

Field

border

Field

border

Field

border

Vegetation

$981 m^{2}$

$1798 m^{2}$

$2655 m^{2}$

$1645 m^{2}$

$1616 \mathrm{~m}^{2}$

$1131 \mathrm{~m}^{2}$ ssp. L.,

Malus domestica ssp. L., Prunus spinosa ssp. L., Prunus domestica ssp. L.,

Faxinus excelsior L., Corylus avellana L., Rubus fruticosus L., Prnus avium

ssp. L,

Carpinus betulus L. Quercus robur L.,

Prunus domestica ssp. L., Fraxinus excelsior L., Corylus avellana L., Prunus spinosa ssp. L.,

Rhamnus cathartica L., Sambucus nigra L., Rosa canina L., Prunus avium ssp. L.,

Quercu robur L., Carpinus betulus L., Rhamnus cathartica L., Corylus

avellana L., Prunus spinosa ssp. L.,

Prunus spinosa L., Fraxinus excelsior L., Rosa canina L.,Prunus avium ssp. L., Pyrus comunis ssp. L.

Corylus avellana L., Acer pseudopltanus L., Fraxinus excelsior L., Prunus

avium ssp. L., Rosa canina L.

Malus domestica ssp. L., Sambucus nigra L., Euonymus europaeus L., Betula pendula Roth., Fagus sylvatica L.,

Acer campestre L., Carpinus betulus L., Malus domestica ssp. L.,

Rosa canina L., Rubus fruticosus L., Carpinus betulus L., Prunus spinosa ssp. L., Prunus domestica ssp. L.,

$\mathbf{7 1 6 m}^{2} \quad$ Sambucus nigra L., Prunus domestica ssp. L., Rosa canina L.

Clematis vitalba L., Fraxinus excelsior L., Malus domestica ssp. L., Prunus

cerasus ssp. L.,

Prunus domestica ssp. L., Clematis vitalba L., Rosa canina L., Acer

platanoides L., Fraxinus excelsior $\mathrm{L}$.

Crataegus monogyna Jack., Prunus domestica ssp. L., Rosa canina L., Quercus

robur L., Rubus fruticosus L.,

Sambusuc nigra L., Acer pseudoplatanus L., Prunus domestica ssp. L.,

Quercus robur L., Fraxinus excelsior L.,

Faxinus excelsior L., Rosa canina L., Prunus domestica ssp. L., Citisus

praecox L., Juglans regia L.,

Prunus avium ssp. L., Prunus spinosa ssp. L., Sambucus nigra L., Fraxinus

excelsior $\mathrm{L}$.,

Crataegus monogyna L., Prunus domestica ssp. L.., Rosa canina L, Fraxinu

excelsior L., Juglans regia L.,

Prunus domestica ssp. L., Rosa canina L., Juglans regia L., Euonymus

europaeus L., Rosa canina L.,

Rhamnus cathartica L., Prunus domestica ssp. L., Sambucus nigra L., Corylus avellana $\mathrm{L}$. ,

Fraxinus excelsior L., Crataeus monogyna Jack., Prunus spinosa ssp. L.,

Prunus avium ssp. L.,

Rosa canina L., Fraxinus excelsior L., Rhamnus cathartica L., Rosa canina L.,

Crataegus monogyna Jack.,

Sambucus nigra L., Prunus avium ssp. L., Fraxinus excelsior L., Rosa canina L.,

Fraxinus excelsior L., Prunus spinosa ssp. L., Robinia pseudoacacia L.,

Prunus domestica ssp. L.,

Prunus domestica ssp. L., Prunus cerasus ssp. L., Sambucus nigra L.,Fraxinus excelsior $\mathrm{L}$.,

Prunus avium ssp. L., Prunus domestica ssp. L., Juglans regia L., Quercus

robu L.,

Prunus spinosa ssp. L., Prunus domestica ssp. L., Prunus avium ssp. L.,

Corylus avellana L., Sambucus nigra L., Rosa canina L., Fraxinus excelsior L.,

Rubus fruticosus L.,

Carpinus betulus L., Fraxinus excelsior L., Prunus spinosa ssp. L..

$\mathbf{8 2 0}^{2} \quad$ Prunus domestica ssp. L., Rosa canina L., Rubus fruticosus L., Salix caprea L., 


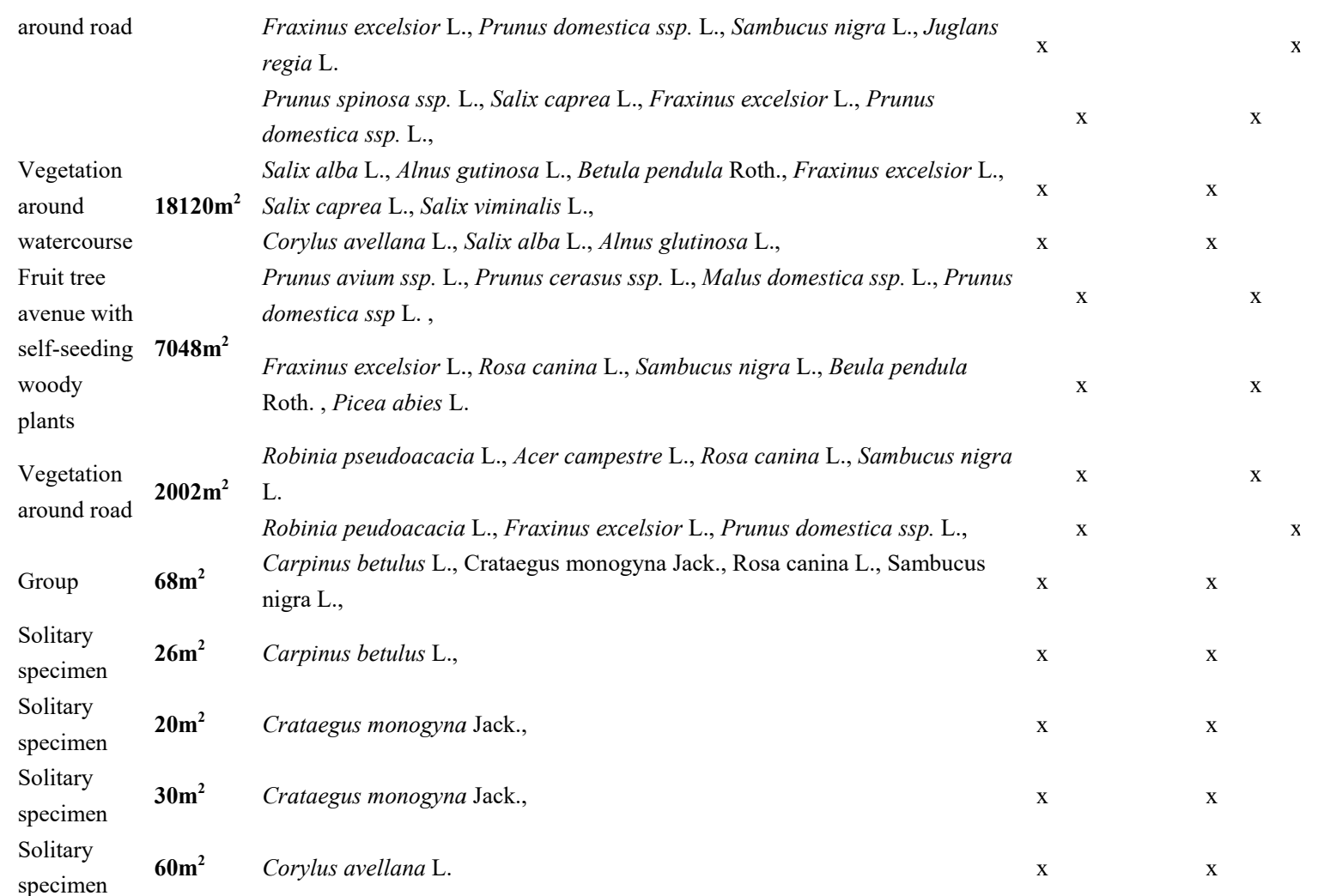

\section{Conclusion}

Statistical evaluation under the research criteria shows that the greatest proportion of non-forest woody vegetation (Fig. 7,8,9) is in the Samopše settlement, where scattered greenery covers $73,928 \mathrm{~m}^{2}$. Conversely, the lowest proportion of non-forest woody vegetation is currently in the settlement of Talmberk covering $7838 \mathrm{~m}^{2}$. The settlement of Př́vlaky has non-forest woody vegetation covering an area of $42,849 \mathrm{~m}^{2}$, the settlement of Budín has $36,365 \mathrm{~m}^{2}$ and the settlement of Mrchojedy has $13,854 \mathrm{~m}^{2}$. The differing areas of non-forest woody vegetation in individual settlements are due to their cultural-historical developments. The management methods and related methods of landscape use (agriculture - Mrchojedy and Př́ivlaky; pasture - Samopše and Př́vlaky; recreation Budín; extraction - Talmberk) have had the greatest impact.

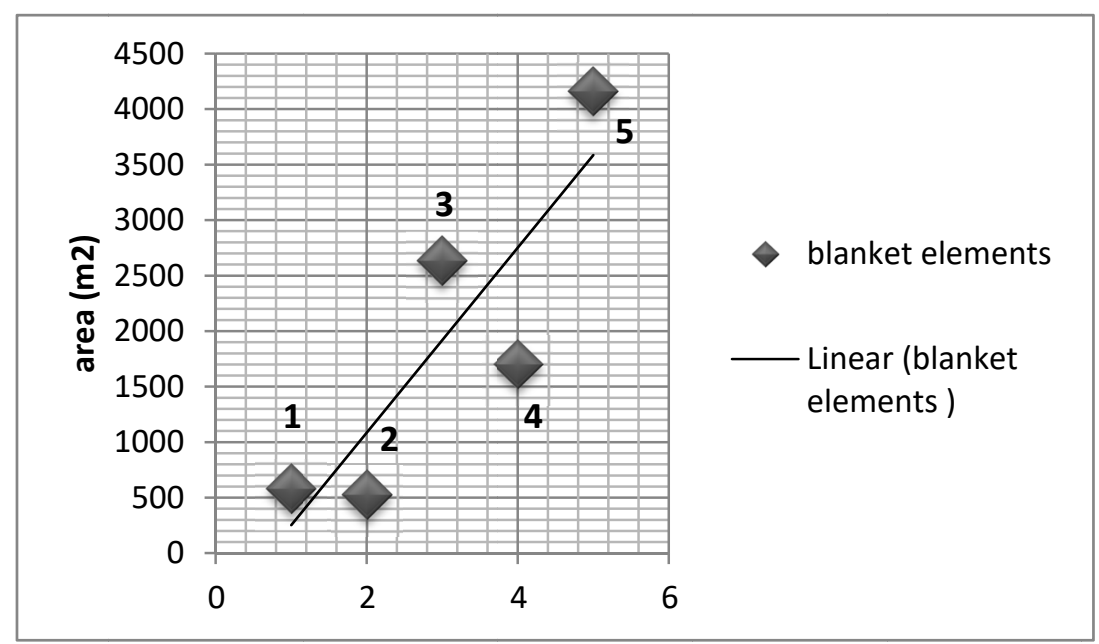

Figure 7. Point graph of the area of blanket non-forest woody vegetation elements at individual settlements of the examined territory. (1) Budín, (2) Samopše, (3) Mrchojedy, (4) Talmberk, (5) Př́vlaky (Source: author's elaboration) 


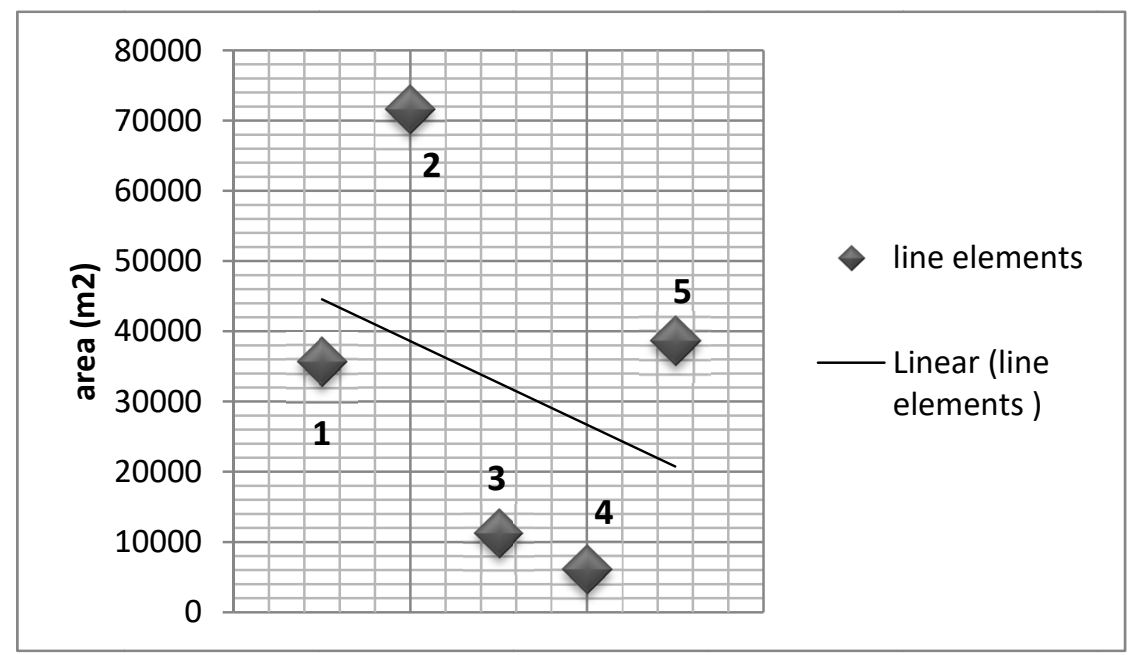

Figure 8. Point graph of the area of non-forest woody vegetation line elements at individual settlements of the examined territory. (1) Budín, (2) Samopše, (3) Mrchojedy, (4) Talmberk, (5) Přívlaky (Source: author’s elaboration)

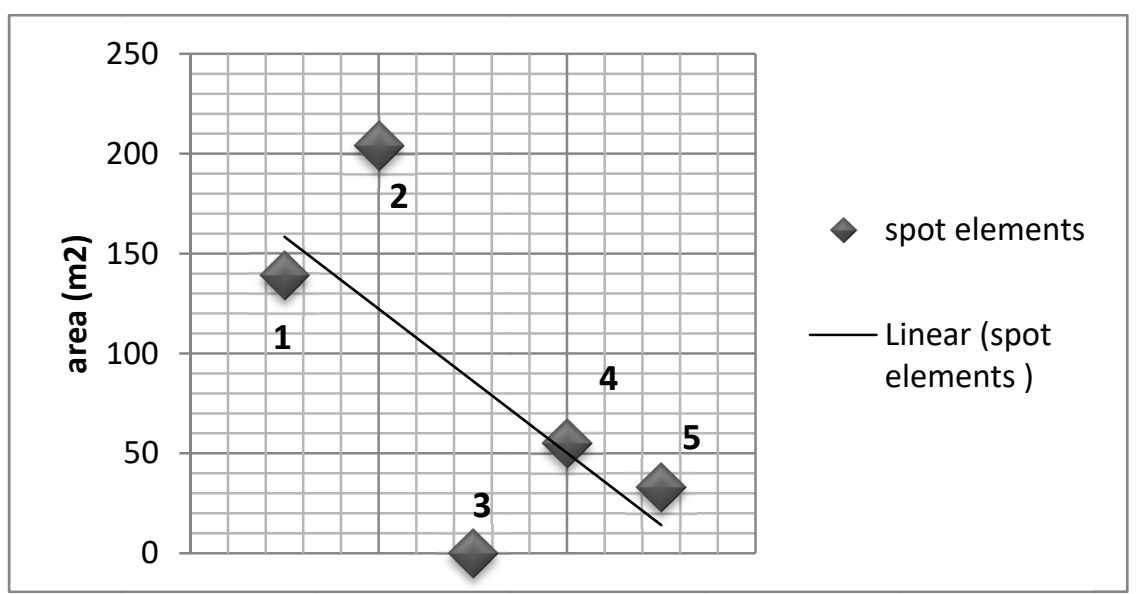

Figure 9. Point graph of the area of non-forest woody vegetation spot elements at individual settlements of the examined territory. (1) Budín, (2) Samopše, (3) Mrchojedy, (4) Talmberk, (5) Přívlaky (Source: author's elaboration)

The range of planted woody vegetation (Fig. 10), which gives the investigated territory its typical identity, is an important aspect. Thirty-nine species of woody vegetation was found in the examined territory. Most of these were deciduous woody plants, the remainder (4) consisted of evergreen species: Norway Spruce (Picea abies L.), Scots Pine (Pinus sylvestris L.), Black Pine (Pinus nigra L.) and Broom (Cytisus praecox L.). The most frequent non-fruiting woody vegetation included European Ash (Fraxinus excelsior L) and Silver Birch (Betula pendula Roth.). Fruiting woody plants most often seen in this territory are Blackthorn (Prunus spinosa ssp. L), Common Plum (Prunus domestica ssp. L), and less frequently, Sour Cherry (Prunus cerasus ssp. L.), Orchard Apple (Malus domestica ssp. L.) and European Pear (Pyrus commnis ssp. L.). Self-seeding woody plants include Rosa canina L. and Sambucus nigra L. Vegetation surrounding watercourses (bodies of water) most often consisted of Common Elder (Alnus glutinosa L), White Willow (Salix alba L.) and Goat Willow (Salix caprea L.). The fruiting species in non-forest woody vegetation elements date from 1930-1938, when over 500 fruit trees (e.g., walnuts - Juglands ssp. L., apples - Malus ssp. L., pears - Pyrus ssp. L., plums - Prunus ssp. L.) were planted in the open and non-forest woody vegetation landscapes of the investigated territory. Maintenance and renewal of non-forest woody vegetation in the model area requires maintenance work (mowing, keeping pastures, caring for old trees, additional planting, pruning, etc.) to be managed. It would be appropriate to 
preserve the current non-forest woody vegetation elements as the last existing fragments and as a legacy of the landscape at the specific location.

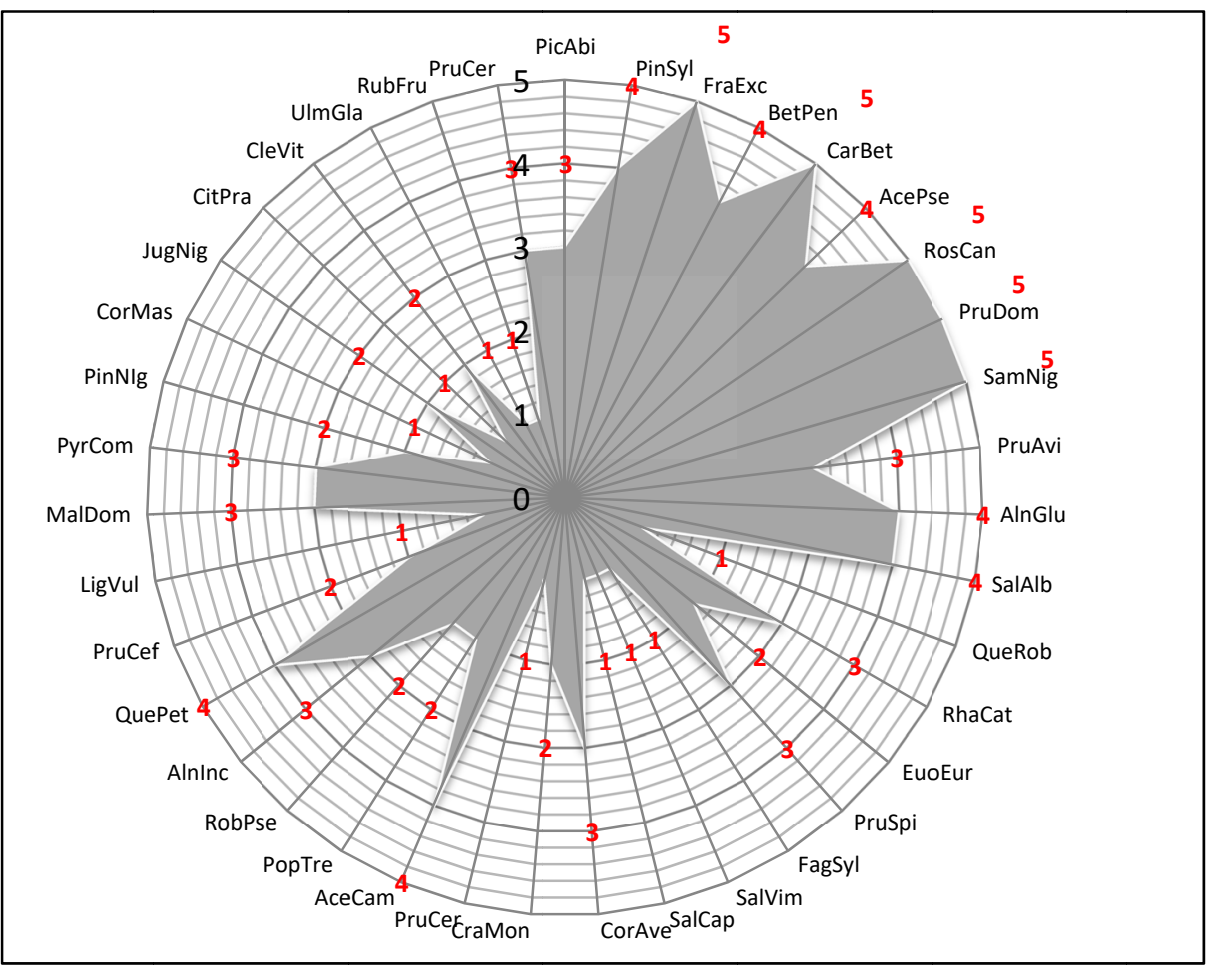

Figure 10. Area graph depicting the occurrence of individual species at the investigated settlements of Budín, Př́ivlaky, Talmberk, Mrchojedy and Samopše. 1 - in one of the five settlements, 2 - in two of the five settlements, $\mathbf{3}$ - in three of the five settlements, $\mathbf{4}$ - in four of the five settlements. (Source: author's elaboration)

Note: PicAbi (Picea abies L.), PinSyl (Pinus sylvestris L.), FraExc (Fraxinus excelsior L.), BetPen (Betula pendula Roth.), CarBet (Carpinus betulus L.), AcePse (Acer pseudoplatanus L.), RosCan (Rosa canina L.), PruDom (Prunus domestica ssp. L.), SamNig (Sambucus nigra L.), PruAvi (Prunus avium ssp. L.), AlnGlu (Alnus glutinosa L.), SalAlb (Salix alba L.), QueRob (Quercus robur L.), RhaCat (Rhamnus cathartica L.), EuoEur (Euonymus europaeus L.), PruSpi (Prunus spinosa ssp. L.), FagSyl (Fagus sylvatica L.), SalVim (Salix viminalis L.), SalCap (Salix caprea L.), CorAve (Corylus avellana L.), CraMon (Crataegus monogyna Jack.), PruCer (Prunus cerasus ssp. L.), AceCam (Acer campestre L.), PopTre (Populus tremula L.), RobPse (Robinia pseudoacacia L.), AlnInc (Alnus incana L.), QuePet (Quercus petraea Matt.), PruCef (Prunus cerasifera ssp. L.), LigVul (Ligustrum vulgare L.), MalDom (Malus domestica ssp. L.), PyrCom (Pyrus communis ssp. L.), PinNIg (Pinus nigra L.), CorMas (Cornus mas L), JugNig (Juglans regia L.), CitPra (Cytisus praecox L.), CleVit (Clematis vitalba L.), UlmGla (Ulmus glabra Huds.), RubFru (Rubus fruticosus L.), PruCer (Prunus cerasifera L.)

The survey of the model area demonstrated the great significance of non-forest woody vegetation existing in the landscape structures of individual settlements (Budín, Přívlaky, Talmberk, Mrchojedy, Samopše) and contributed to the general rules for establishing, proposing, evaluating and maintaining the function of non-forest woody vegetation elements. The overall occurrence of landscape greenery in the landscape model, according to individual solutions in the village territories, demonstrates the prevalence of this element in this landscape character. In a comparison of individual landscape elements, the irreplaceability of scattered vegetation in this landscape character was shown. Preservation of scattered vegetation is an essential condition for maintaining the features of this landscape character. 


\subsection{General Rules for Establishing, Proposing, Evaluating and Maintaining the Function of Non-Forest Woody Vegetation Elements}

When proposing and establishing woody vegetation elements, it is important to consider what their function and final character will be. The proposed spatial and species structure is based on local conditions, their required function, and the character of the landscape. The regional characteristics of non-forest woody vegetation may differ significantly and have typical forms for each region. These forms are based on natural conditions and the traditional management and maintenance methods and technologies. Traditional forms of non-forest woody vegetation may serve as an example for establishing new woody biotopes in the area. Their function, location in space and their species and spatial structures may be used as examples. When establishing woody elements, we prefer autochthonous species to introduced species. We can base a selection of suitable taxons on the species structure of woody formations in the area we want to establish the element in. When planning the species structure of woody elements, we must combine slow-growing (long-lived) species with fast-growing (short-lived) species (Forman \& Gordon, 1993).

Evaluating non-forest woody vegetation is an important part of assessing the landscape in the field of landscape ecology. Multiple methodological approaches are available to evaluate non-forest woody vegetation, which can be divided into four groups depending on the purpose of the evaluation: (a) biological - evaluation of the current condition of woody plants, their physiognomic properties, species identification, function (ecosystem, biotope) with the goal of conservation of nature and biodiversity; (b) functional - determination of the functional use of non-forest woody vegetation from the viewpoint of humans, determination of functional relationships with the goal of protecting agricultural land and securing the polyfunctionality of the landscape; (c) landscape evaluation of the aesthetic integration of non-forest woody vegetation into the landscape's composition using dendrological evaluation of non-forest woody vegetation (species, crown shape, tree height); (d) historical evaluation of dynamic space-time changes in non-forest woody vegetation, development of the overall occurrence and structure of the landscape (Baudry, Bunce \& Burel, 2000).

Woody elements, particularly those whose origin is conditional to human activity, require the corresponding care in order to maintain their required functions and achieve a sufficient lifespan. The intensity of this care and the nature of intervention into woody vegetation elements is governed by the developmental stage of these woody plants, the species of woody plants and the function and the target condition of the non-forest woody biotope. Maintaining existing non-forest woody vegetation elements will differ from the care of newly established elements (Sláviková, 1987). The function of EXISTING non-forest woody vegetation is maintained by considerate intervention consisting of maintenance care (pruning, thinning and additional planting) in order to assure the long-term prospects of individual elements. By contrast, PROPOSED non-forest woody vegetation elements require initial developmental care (tree anchoring, chemical protection of the planted woody plants, grass mowing, training) during the first years after planting, which leads to rapid and high-quality fulfilment of the function of woody growth and to the creation of elements with the smallest possible demands in maintenance and care. The transition to maintenance and care takes place in subsequent years and should happen gradually over areas and time. The types of measures and appropriate intervals depend heavily on the type of woody vegetation.

The restoration of high-quality, scattered non-forest woody vegetation in the landscape is an essential condition for stopping the process of destabilisation of the agrarian landscape and the depletion of natural biodiversity, as well as renewing the diversity of the landscape and the life it contains (Vondra Krupková, 2018).

\section{Discussion}

The concept of non-forest woody vegetation is currently a heavily discussed topic. Studies not only concerning the Czech Republic may serve as example. Authors also discuss various forms of non-forest woody vegetation in foreign literature. Scattered woody vegetation is the subject of studies by the collective authors Manning, Fischer \& Lindenmayer (2006). Gibbons et al. (2008). Plieninger, Pulido \& Schaich (2004); Plieninger, Schleyer, Mantel \& Hoster, (2012) discuss trees growing outside forestsLine elements such as hedgerows are discussed in Great Britain and France (Pollard et al. (1974); Burel \& Baudry (1990); Mérot (1999); Oreszczyn \& Lane (1999); McCollin (2000); Petit, Stuart, Gillespie \& Barr, (2003); Ernoult \& Alard (2011), etc.)..Windbreaks in Poland are discussed, for example, by Ryszkowski \& Kedziora (2007), and in Denmark by Kristensen \& Caspersen (2002).

While non-forest woody vegetation was a normal part of the agricultural landscape in the past and created the landscape's typical appearance, the onset of collective farming during the second half of the twentieth century transformed the landscape into an environment of open fields without permanent vegetation (Meeus, 1995). 
Non-forest woody vegetation is a characteristic feature of many European landscapes (Burel \& Baudry 1995). Similar landscapes are currently rare in Central and Eastern Europe (Riezner, 2008). Technological changes and the intensification and mechanisation of agriculture had similar consequences in both Eastern and Western Europe (Burel \& Baudry, 1990; Barr \& Gillespie, 2000; Jongman, 2002; Plieninger, Schleyer, Mantel \& Hoster, 2012). McCollin (2000) emphasises that during the period 1984-1994, some 158,000 km of hedgerows were lost from the British landscape, i.e., a third of their total existing length in 1984. Jongman (2002) states that the total length of line vegetation structures in Holland fell by $80 \%$ over a period of 80 years. This information illustrates that the elimination and reduction of areas of non-forest woody vegetation in open agricultural landscapes is not only applicable to the former Czechoslovakia (Pollard, Hooper \& Moore, 1974; Burel \& Baudry, 1990; Mérot, 1999; Oreszczyn \& Lane, 1999; Petit, Stuart, Gillespie \& Barr, 2003; French \& Cummins, 2001; Ernoult \& Alard, 2011).

Line vegetation is an important part of scattered greenery (Bennet, 1990). Solitary woody plants or vegetation surrounding watercourses consist mainly of autochthonous species. Scattered greenery in the form of woody plants in field boundaries and groves occurs to a lesser degree in the deforested areas of meadows and pastures near settlements are frequent elements of scattered greenery are an important tool for harmonising the landscape (Kavka \& Šindelářová, 1978). A key feature of the Czech countryside is a persistent close link to specific areas and types of woody plant with specific time periods. The identity of greenery has become an important feature of the landscape's character (Bulî́ \& Škorpík, 1988).

\section{Acknowledgements}

Author thanks village Samopše for granting the right to publish Aerial photographs in Figures 2, 3, 4, 5, 6.

\section{References}

Barr, C.J., \& Gillespie, M.K. (2000). Estimating hedgerow length and pattern characteristics in Great Britain using Countryside Survey data. Journal of Environmental Management, 60, 23-32. Retrieved from https://doi.org/10.1006/jema.2000.0359

Baudry, J., Bunce, R.G.H., \& Burel, F. (2000). Hedgerows: An international perspective on their origin, function and management. Journal of Environmental Management, 60, 7-22. Retrieved from https://doi.org/10.1006/jema.2000.0358

Bennet, A. F. (1990). Habitat corridors and the conservation of small mammals in fragmented forest environment. Landscape ecology, 4(2/3), 109-122. https://doi.org/10.1007/BF00132855

Buliř, P., \& Škorpík, M. (1987). Rozptýlená zeleň, VŠÚOZ, Průhonice.

Burel, F., \& Baudry, J. (1990). Structural dynamic of a hedgerow network landscape in Brittany France. Landscape Ecology, 4, 197-210. 010.1007/BF00129828

Cílek, V., \& Ložek, V. (2011). Obraz krajiny, Dokořán.

Doucha, T. (2001). Péče o zemědělskou krajinu - ekonomicky zajímavá komodita. Sborník konference Tvár̆ naši zemé - krajina domova, svazek úvodní (pp. 225-235). ČKA, Praha.

Ernoult, A., \& Alard, D. (2011). Species richness of hedgerow habitats in changing agricultural landscapes: are alpha and gamma diversity shaped by the same factors? Landscape Ecology, 26, 683-696. https://doi.org/ 10.1007/s10980-011-9593-3

Forman, R.T.T., \& Gordon. (1993). M. Krajinná ekologie. Praha: Academia

French, D.D., \& Cummins R.P. (2001). Classification, composition, richness and diversity of British hedgerows. Appl. Veget. Sci., 4, 213-228. Retrieved from https://doi.org/10.1111/j.1654-109X.2001.tb00490.x

Gibbons, P., Lindenmayer, D.B., Fischer, J., Manning, A.D., Weinberg, A., Seddon, J., Ryan, P., Barrett, G. (2008). The future of scattered trees in agricultural landscapes. Conserv. Biol., 22, 1309-1319. https://doi.org/10.1111/j.1523-1739.2008.00997.x

Jongman, R.H.G. (2002). Homogenisation and fragmentation of the European landscape: ecological consequences and solutions. Landscape and Urban Planning, 58(2-4), 211-221. Retrieved from http://dx.doi.org/10.1016/S0169-2046(01)00222-5

Kavka, B., Šindelářová, J. (1978). Funkce zelene v životním prostredí. Praha, Státní zemedelské nakladatelství.

Koblížek, J. (2000). Jehličnaté a listnaté dřeviny našich zahrad a parků. Praha, Sursum a Freedom DTP studio. 
Kristensen, S. P., \& Caspersen, O. H. (2002). Analysis of changes in a shelterbelt network landscape in central Jutland, Denmark. Journal of Environmental Management, 66(2), 171-183. Retrieved from https://doi.org/10.1006/jema.2002.0582

Líbrová, H. (2011). Decentralizace osídlení - vize a realita. Sociologický časopis. 1996. roč. 32, č. 3. Retrieved from: http://sreview.soc.cas.cz/cs/issue/94-sociologicky-casopis-3-1996

Lipský, Z. (2000). Experience in assessment of landscape character. Ekológia/Ecology (Bratislava), 19(Supp. 2), 188-198,

Lokoč, R., Lokočová, M., \& Kolářová Šulcová, M. (2010). Vývoj Krajiny v České republice, (2B06126). Retrieved from http://www.lowaspol.cz/_soubory/KR_kniha.pdf

Löw J., \& Míchal, I. (2003). Krajinný ráz. Kostelec nad Černými lesy: Lesnická práce (pp. 12-19). CZ.

Löw, J, \& Novák, J. (2006). Typologické členění krajin České Republiky. Urbanismus a územní rozvoj. Ročník XI. Výzkumný úkol MŽP. VaV/640/1/03. Retrieved from https://www.uur.cz/images/5-publikacni -cinnost-a-knihovna/casopis/2008/2008-06/06 typologicke.pdf

Mareček, J. (1986). Zeleň ve venkovských sídlech a v jejich krajinném prostředí. RŽP - SNZ Praha, CZ

McColin, D. (2000). Hedgerow policy and protection - changing paradigms and the conservation ethic. Journal of Environmental Management, 60, s. 3-6. http://doi.org/10.1006/jema.2000.0357

Meeus, J. (1995). Pan-European landscapes. Landsc. Urban Plan., 31, 57-79.

Mérot, P. (1999). The influence of hedgerow systems on the hydrology of agricultural catchments in a temperate climate. Agronomie, 19, 655-669. Retrieved from https://hal.archives-ouvertes.fr/hal-00885959

Neuhäslová, Z., Blažková, D., Grulich, V., Husová, M., Chytrý, M., Jeník, J., ... Sádlo, J.(1998). Mapa potenciální prirozené vegetace České republiky. Textová část. Praha: Academia

Oreszczyn S., Lane A. (1999). How hedgerows and field margins are perceived by different interest groups. Aspects of Appl. Biol., 54, 29-36.

Petit, S., Stuart, R.C., Gillespie, M.K., \& Barr, C.J. (2003). Field boundaries in Great Britain: stock and change between 1984, 1990 and 1998. Journal of Environmental Management, 67, s. 229- 238. https://doi.org/10.1016/S0301-4797(02)00176-7

Petrán̆ J. a kol. (1985). Déjiny hmotné kultury I, Praha, Karolinum.

Plieninger, T., Pulido, F.J., \& Schaich, H. (2004). Effects of land-use and landscape structure on holm oak recruitment and regeneration at farm level in Quercus ilex L. dehesas. J. Arid Environ., 57, $345-364$. http://doi.org/10.1016/S0140-1963(03)00103-4

Plieninger, T., Schleyer, CH., Mantel, M., \& Hoster, P. (2012). Is there a forest transition outside forests? Trajectories of farm trees and effects on ecosystem services in an agricultural landscape in Eastern Germany. Land Use Policy, 29, s. 233-243. http://doi.org/10.1016/j.landusepol.2011.06.011

Pollard, E., Hooper, M.D., \& Moore, N.W. (1974). Hedges. Collins, London.

Prudký, J. (2001). Obnova plošné a bodové zeleně v krajině. In Obnova plošné a bodové zeleně. Sborník přednášek z mezinárodního semináře, Brno.

Riezner, J. (2008).Záhumenicová semibocage: typ krajinného rázu Jesenicka. Geografie, 113(2), s. 173-182.

Ryszkowski, L., \& Kedziora, A. (2007). Modification of water flows and nitrogen fluxes by shelterbelts. Ecol. Engin., 29, 388-400. http://doi.org/10.1016/j.ecoleng.2006.09.023

Schama, S. (1995). Ladscape and memory, Knopf New York.

Sklenička, P. (2003). Základy krajinného plánování. Praha Naděžda Skleničková.

Sláviková, D. (1987). Ochrana rozptýlenej zelene v krajine. Metodicko-námetová prírucka c. 9. ÚV Slovenského zväzu ochrancov prírody a krajiny, Bratislava.

Supuka, J., Schlampová, T., \& Jančura, P. (1999). Krajinárska tvorba. Technická univerzita

Trnka, P. (2001). Ekologické aspekty plošné a bodové zeleně v krajině. In Obnova plošné a bodové zeleně v krajině. Sborník z mezinárodního semináře. Brno: MZLU v Brně,

Trnka, P. (2007). Proměny krajiny venkova a role rozptýlené zeleně v krajině. Rukopis pro ICV - CŽV MZLU v Brně. Sborník z mezinárodního semináře. Brno: MZLU v Brně 
Vondra Krupková, Z. (2018). System of non-forest woody vegetation considered in relation to the landscape character (face) and impact on it. Journal of Urban Planning, Landscape \& environmental Design, 3(1), 25-36. Retried from http://upland.it/index.php/UPLanD/article/view/115/83

\section{Copyrights}

Copyright for this article is retained by the author(s), with first publication rights granted to the journal.

This is an open-access article distributed under the terms and conditions of the Creative Commons Attribution license (http://creativecommons.org/licenses/by/4.0/). 